\title{
Momordica balsamina: phytochemistry and pharmacological potential of a gifted species
}

\author{
Cátia Ramalhete • Bruno M. F. Gonçalves · Filipa Barbosa • Noélia Duarte • \\ Maria-José U. Ferreira ${ }^{(1)}$
}
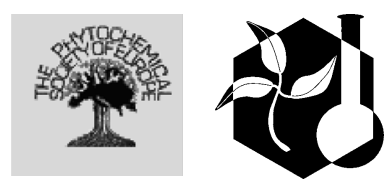

Received: 8 July 2021 / Accepted: 9 January 2022/Published online: 8 February 2022

(C) The Author(s), under exclusive licence to Springer Nature B.V. 2022

\begin{abstract}
Momordica balsamina L. (Cucurbitaceae), frequently named balsam apple, southern balsam pear or African pumpkin, is a vegetable with high nutritional value, being mostly used as food in sub-Saharan Africa. It has also been largely used in traditional medicine to treat several diseases, such as malaria fevers and diabetes. As a member of the Cucurbitaceae family, the main constituents are cucurbitane-type triterpenoids, with different oxidation patterns, named cucurbitacins. This review aims at summarizing our contribution to the phytochemical study of M. balsamina and the evaluation of the isolated cucurbitacins and derivatives as multidrug resistance reversers in cancer cells and bacteria. In this way, the selective antiproliferative activity against multidrug resistant cancer cells of cucurbitacins obtained from M. balsamina, their ability as P-glycoprotein inhibitors in cancer cells overexpressing this $\mathrm{ABC}$ transporter, as well as efflux pump inhibitors in
\end{abstract}

C. Ramalhete · B. M. F. Gonçalves .

F. Barbosa - N. Duarte · M.-J. U. Ferreira $(\square)$

Research Institute for Medicines and Pharmaceutical

Sciences (iMed.ULisboa), Faculty of Pharmacy,

Universidade de Lisboa, Av. Prof. Gama Pinto,

1649-003 Lisboa, Portugal

e-mail: mjuferreira@ff.ulisboa.pt

C. Ramalhete

ATLÂNTICA - Instituto Universitário, Fábrica da Pólvora de Barcarena, Barcarena, Oeiras 2730-036, Portugal resistant bacteria strains are reviewed. Moreover, the in vitro antimalarial activity of cucurbitacins and acyl derivatives against the blood and liver-stages of Plasmodium strains, and the in vivo activity of selected compounds is also reviewed. Besides our work, edible and medicinal uses, and other studies mainly reporting the biological activities of $M$. balsamina extracts, such as antidiabetic, antibacterial, anti-inflammatory, and antioxidant properties are also addressed.

Keywords Momordica balsamina - Cucurbitaceae . Cucurbitane-type triterpenoids - Traditional medicine $\cdot$ Multidrug resistance $\cdot$ Antimalarial

\section{Introduction}

Cucurbitaceae family, generally known as the cucumber, gourd, melon, or pumpkin family, comprises 120 genera and around 965 species, mainly disseminated in tropical and subtropical regions of the world (Omokhua-Uyi and Van Staden 2020). Some of the most important genera of this family are Benincasa, Bryonopsis, Citrullus, Cucumis, Cucurbita, Luffa, Momordica and Trichosanthes (Dhiman et al. 2012). Momordica genus embraces over 60 species, including $M$. balsamina, M. charantia, $M$. cochinchinensis and $M$. foetida, which are distributed in the warm 
tropics, predominantly in Africa and in Southeast Asia. The name of the genus derives from the Latin word "mordeo" that means "to bite", either because of the bitten appearance of the indented margins of the seeds and leaves, or for the well-known bitter taste of the ripe fruits of some of its species (Bharathi and John 2013).

Momordica balsamina L., commonly named balsam apple, southern balsam pear or African pumpkin, is native to the African tropical regions, occurring also in Asia, India and Australia. It is also widely found in tropical America, probably as a result of human introduction (Thakur et al. 2009; Omokhua-Uyi and Van Staden 2020). The plant is a monoecious annual or short-lived perennial herb with stems that can reach $5 \mathrm{~m}$ long, with simple alternate lobed leaves and tendrils for attachment. It has trumpet-shaped, pale yellow, cream or white flowers and bright orange to red ovoid-ellipsoid fruits of $2.5-4.5 \mathrm{~cm}$ long (Deutschlnder et al. 2009; Thakur et al. 2009) (Fig. 1). M. balsamina is a vegetable with high nutritional value, in particular its young fruits, being mostly used as food in sub-Saharan Africa. In addition, its use in traditional medicine, particularly in African countries, has also been reported (Thakur et al. 2009). For these reasons, this species has been regarded as a gifted plant by some rural populations. Some reviews have been published about Cucurbitaceae and Momordica species, particularly focusing on Momordica charantia, the most studied species of the genus (Dhiman et al. 2012; Bharathi and John 2013; Shah et al. 2014; Omokhua-Uyi and Van Staden 2020; Muronga et al. 2021). Different aspects of $M$. balsamina have also been reported in these reviews, mostly covering its nutritional and medicinal properties. Nevertheless, apart from the review of (Thakur et al. 2009) that was totally dedicated to M. balsamina, the information about this species is scattered, and a comprehensive review embracing all knowledge and the most recent research studies on M. balsamina extracts and isolated compounds is still missing.

In this review, the current knowledge on $M$. balsamina is highlighted, aiming at summarizing our contribution to the phytochemical study and biological evaluation of the main cucurbitane-type triterpenes isolated from M. balsamina or obtained by derivatization of the major compounds, namely their ability to reverse multidrug resistance in cancer, and antimalarial activity. Furthermore, other studies related to both

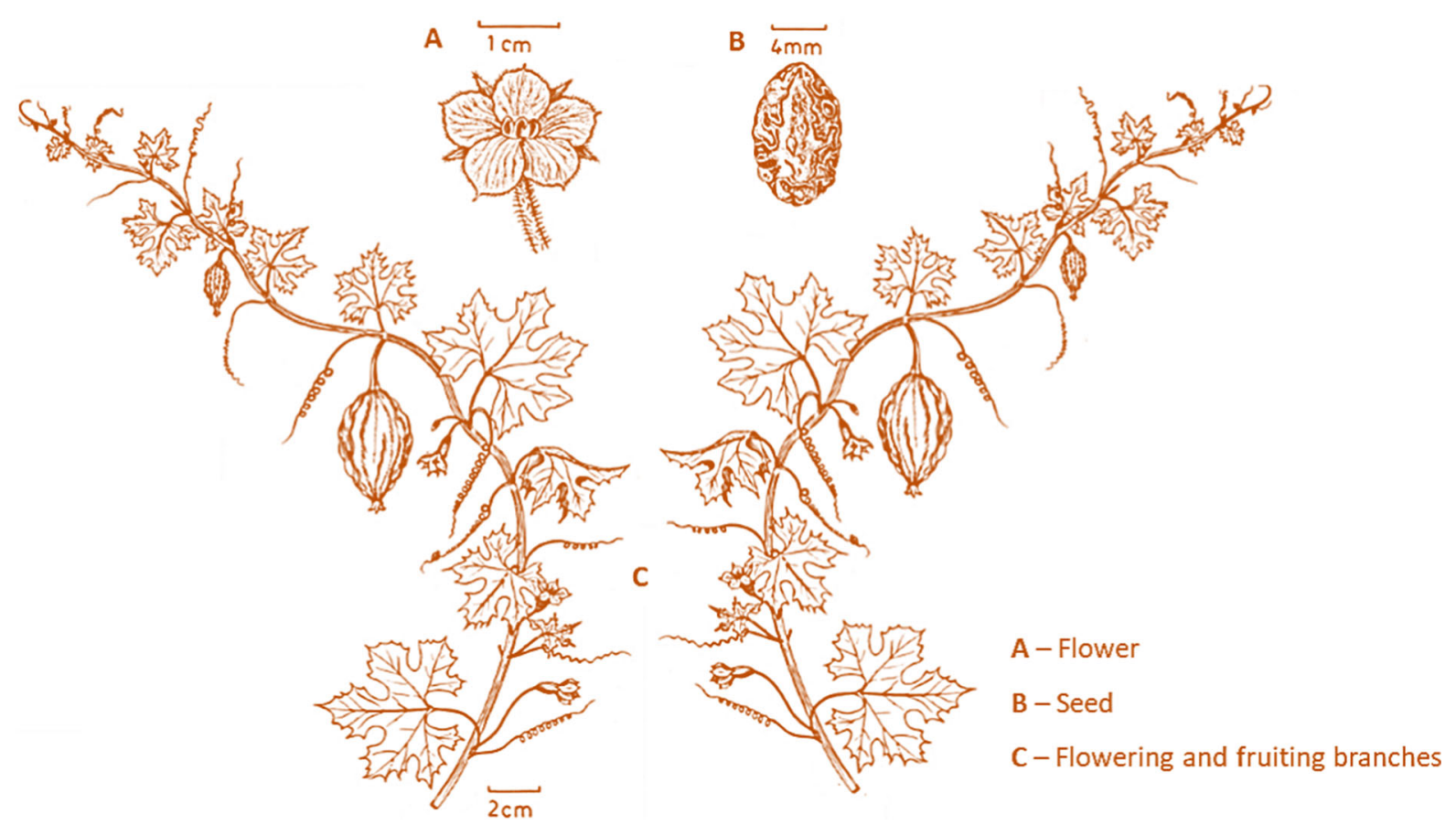

Fig. 1 Momordica balsamina (adapted from Tropicos.org. 2021) 
natural compounds or extracts and corresponding bioactivities are also reviewed.

\section{Literature search}

The literature search was conducted from October 2020 to June 2021 using research databases containing peer-reviewed articles (Web of Science, ScienceDirect, PubMed, Scopus, and Google Scholar) in order to identify relevant studies. Some books and official websites were also accessed. The key word Momordica balsamina was used truncated with other relevant topic terms, such as, traditional medicine, multidrug resistance, antimalarial, antibacterial, antiviral, antidiabetic, and antioxidant. Only peer-reviewed research articles, reviews, and books published in English were considered, and no time restrictions for publication were applied. The authors individually screened the literature, and exclusion criteria were defined, including, poor quality, inaccurate data or not considered relevant to the aim of the review. Mendeley desktop software was used to manage the references and eliminate duplicates.

\section{Edible and medicinal uses}

Besides growing widely, Cucurbitaceae have become one of the plant families most cultivated around the world (Shah et al. 2014; Omokhua-Uyi and Van Staden 2020). Some of the most economically important cucurbits include watermelon (Citrullus lanatus), melon (Cucumis melo), cucumber (Cucumis sativus), pumpkin (Cucurbita maxima), zucchini (Cucurbita pepo) and bitter gourd (M. charantia), all of them cultivated for their fruit (Chomicki et al. 2020). Other minor crops are of more local commercial importance and are cultivated for varied purposes including the use as a low-calorie sweetener (Siraitia grosvenorii), nutritious seeds or seeds used to make oil (Citrullus lanatus, Zehneria scabra and Telfairia occidentalis) and medicinal uses (Citrullus colocynthis, M. charantia and M. balsamina) (Chomicki et al. 2020; Omokhua-Uyi and Van Staden 2020).

M. balsamina has both nutritional and medicinal properties, being considered a gift of nature for some communities (Thakur et al. 2009). Fruits and leaves of $M$. balsamina have been used as food by African and
Asian rural communities. The unripe fruits and leaves are cooked and eaten in Southern Africa, Cameroon, Sudan and India, while the bright red fruit pulp is eaten in Namibia. Curiously, the bitter young fruits are reported as edible, whereas the mature fruits are described as causing vomiting and diarrhea. The toxicity of fruits has been associated with the presence of alkaloids, resins and saponin glycosides. The leaves and fruits are sometimes used in sauces and soups. In Botswana, the leaves are cooked and served as a porridge by the rural communities (Flyman and Afolayan 2007; Bharathi and John 2013; OmokhuaUyi and Van Staden 2020).

The nutritional composition of the M. balsamina may be variable, probably depending on farming practices and prevailing environmental conditions (Bharathi and John 2013). Nevertheless, the plant leaves have a high content of protein, carbohydrate, and fiber, whereas the fat content and energy value (191 kcal/100 g dry weight) are low. On the other hand, the ash content is relatively high in leaves, corroborating its potential as a source of minerals in human diets, particularly $\mathrm{K}, \mathrm{Ca}, \mathrm{Mg}, \mathrm{Fe}, \mathrm{Cu}, \mathrm{Zn}$, and Mn (Hassan and Umar 2006; Flyman and Afolayan 2007). In this way, M. balsamina could be considered as a promising and important source of protein, carbohydrate and minerals for poor rural communities.

The fruits, leaves, roots and seeds of M. balsamina have been used, either as decoction, infusion, poultice or as herbal tea, for several medicinal purposes in different provinces of Asia and Africa, including Eastern Cape, Limpopo, Northern Cape, Western Cape, KwaZulu-Natal (Omokhua-Uyi and Van Staden 2020). Moreover, extracts from different parts of this plant have been reported to have antiplasmodial (Benoit-Vical et al. 2006), antiviral (Bot et al. 2007), anti-inflammatory, analgesic (Karumi et al. 2003), shigellocidal (Bot et al. 2007), anti-diarrheal (Akinyemi et al. 2005), antiseptic and antimicrobial activities (Otimenyin et al. 2008). Data gathered from the reviewed literature are summarized in Table 1, illustrating the use of M. balsamina for the traditional treatment of various health problems. Detailed information concerning the traditional use of medicinal plants has greatly contributed for the success of natural product-derived compounds in drug discovery and development. Unfortunately, concerning M. balsamina, as in other Momordica species, the data related to the traditional use of this plant by indigenous tribes are 
Table 1 Ethnopharmacological uses of Momordica balsamina

\begin{tabular}{|c|c|c|c|}
\hline $\begin{array}{l}\text { Plant } \\
\text { part }\end{array}$ & Ethnomedicinal uses & $\begin{array}{l}\text { Preparation/ } \\
\text { method used }\end{array}$ & Reference \\
\hline \multicolumn{4}{|l|}{ Whole } \\
\hline \multirow[t]{12}{*}{ Plant } & As a bitter stomachic & & Thakur et al. (2009) \\
\hline & As a wash for the treatment of fevers and yaws & Infusion & \\
\hline & To stimulate lactation & Maceration & \\
\hline & To relieve intercostal pains & Maceration & \\
\hline & To treat vomiting associated with bile and fever (Africa) & & Bandeira et al. (2001) \\
\hline & As an ingredient in aphrodisiac preparations & & Karumi et al. (2003) \\
\hline & To treat externally malignant ulcers & Pulverization & \\
\hline & To treat stomach and intestinal complaints (South Africa) & & Bharathi and John (2013) \\
\hline & As an anthelminthic (Asia) & Sponge & \\
\hline & To treat skin problems & & $\begin{array}{l}\text { Karumi et al. (2003), Thakur et al. } \\
\text { (2009) }\end{array}$ \\
\hline & As tranquilizer to treat mental illness & & \\
\hline & To treat liver diseases (South African) & & $\begin{array}{l}\text { Omokhua-Uyi and Van Staden } \\
\text { (2020) }\end{array}$ \\
\hline \multirow[t]{7}{*}{ Leaves } & $\begin{array}{l}\text { To stabilize glycaemia levels in diabetic patients (South } \\
\text { Africa) }\end{array}$ & Decoction & Mokganya and Tshisikhawe (2019) \\
\hline & To treat burns & Poultice & \\
\hline & To treat malaria (Niger) & $\begin{array}{l}\text { Decoction or } \\
\text { Infusion }\end{array}$ & Benoit-Vical et al. (2006) \\
\hline & As an antibiotic (Nigeria) & & Mshelia et al. (2017) \\
\hline & To treat abdominal pain (Nigeria) & Aqueous extract & \\
\hline & $\begin{array}{l}\text { To induce lactation and regenerate the loss of blood during } \\
\text { labor (Nigeria) }\end{array}$ & Cooked & Uchegbu et al. (2015) \\
\hline & To treat extreme uterine bleeding (Asia) & & Bharathi and John (2013) \\
\hline \multirow[t]{4}{*}{ Root } & To induce abortion (India) & & $\begin{array}{l}\text { Karumi et al. (2003), Bharathi and } \\
\text { John (2013 }\end{array}$ \\
\hline & To treat fever & & Van Wyk et al. 2008) \\
\hline & To treat stomach cramp & Tea & \\
\hline & To treat diarrhea & & Thakur et al. (2009) \\
\hline \multirow[t]{6}{*}{ Fruit } & To induce abortion (Nigeria and Ghana) & & Karumi et al. (2003) \\
\hline & As a purgative agent (Senegal) & & Thakur et al. (2009) \\
\hline & Used as vermifuge (Senegal) & & \\
\hline & To treat wounds (Nigeria) & & \\
\hline & To treat chapped hands, burns and hemorrhoids & Liniment & Mshelia et al. (2017) \\
\hline & To treat AIDS & & Bot et al. (2007) \\
\hline
\end{tabular}

often poorly documented in the available literature (Bharathi and John 2013).

\section{Cucurbitacins: general and biosynthetic considerations}

Several plants from the Cucurbitaceae family are characterized by their high content of cucurbitacins, a group of structurally diverse, highly oxygenated triterpenes. These secondary metabolites are most 
abundant in Bryonia, Citrullus, Cucumis, Cucurbita, Echinocystis, Lagenaria, Luffa and Momordica genera (Kaushik et al. 2015). Several cucurbitacins have been also isolated from other plant families, including Brassicaceae, Begoniaceae, Rosaceae, Scrophulariaceae and Thymelaeaceae (Kaushik et al. 2015; Jing et al. 2020). Cucurbitacins are bitter compounds and for this reason, they are likely to be synthetized as oviposition or feeding deterrents for many insects, or as a defense role to protect plants against herbivores (Ríos et al. 2005).

Cucurbitacins can be found in several plant organs. For example, in Cucurbita andreana and Citrullus colocynthis, cucurbitacins were isolated from the fruits, while in Cayaponia tayuya, Bryonia alba, and Bryonia dioica they were isolated from roots or rhizomes (Ríos et al. 2005). In M. balsamina, these triterpenes were found in the aerial parts of the plant (leaves and stems) (Ferreira et al. 2014).

The basic scaffold of cucurbitacins, $19(10 \rightarrow 9 \beta)$ abeo-10 $\alpha$-lanost-5-ene, also known as 9 $\beta$-methyl-19norlanost-5-ene, is depicted in Fig. 2. They can be found in either free or glycosidic form, and possess a high variety of oxygenated functional groups and unsaturations, giving rise to a great number of structurally diverse compounds. In this way, cucurbitacins have been randomly divided into several categories, comprising cucurbitacins A-T, according to variations in their side-chains, presence of various functional groups in the tetracyclic scaffold, and stereochemical features (Chen et al. 2005; Kaushik et al. 2015; Kim et al. 2020).

Currently, these compounds are also named taking in consideration a specific chemical modification, or the name of the genus or species from which they were isolated. Some less common cucurbitacins include rearranged compounds with a fifth ring (e.g. cucurbitacin S, isolated from Bryonia dioica), nor-derivatives, and compounds possessing an aromatic A ring (e.g. fevicordin A, isolated from Fevillea cordifolia) or a A-ring lactone (e.g. neocucurbitacin A, isolated from Luffa operculata) (Fig. 3) (Chen et al. 2005). Recently, a unique 5/6/3/6/5-fused pentacyclic carbon skeleton, named cucurbalsaminane (Fig. 2), was found out by our group, following the isolation of cucurbalsaminones A-C (40-42, Fig. 8) from $M$. balsamina (Mónico et al. 2019).

Similarly to other tetracyclic triterpenes, cucurbitacins are formed through the enzymatic cyclization reaction of (3S)-2,3-oxidosqualene by a specific triterpene synthase (Fig. 4). For a long period of time, cucurbitacins were assumed to be derived from the same biosynthetic route as lanosterol, cycloartenol or parkeol (Shibuya et al. 2004; Hu et al. 2020). Nevertheless, experimental evidence has confirmed that a specific enzyme, cucurbitadienol synthase, is responsible for the chair-boat-chair cyclization of 2,3(S)-oxidosqualene (Fig. 4) (Shibuya et al. 2004). Although cucurbitadienol and cycloartenol synthases share some common steps, the formation of lanosteryl
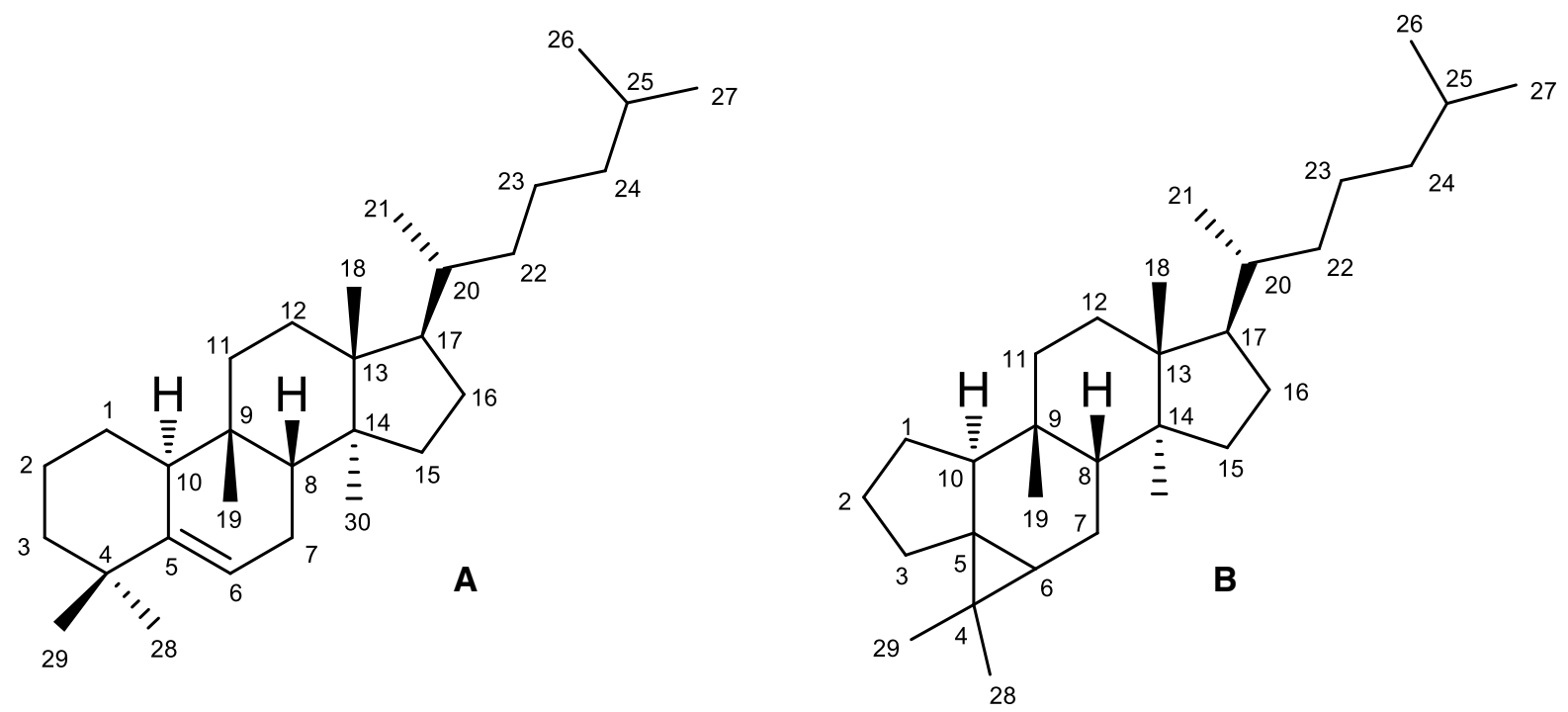

Fig. 2 Basic scaffold of cucurbitacins $(19(10 \rightarrow 9 \beta)$-abeo-10 $\alpha$-lanost-5-ene) $(\mathbf{A})$, and the new cucurbalsaminane skeleton $(\mathbf{B})$ 


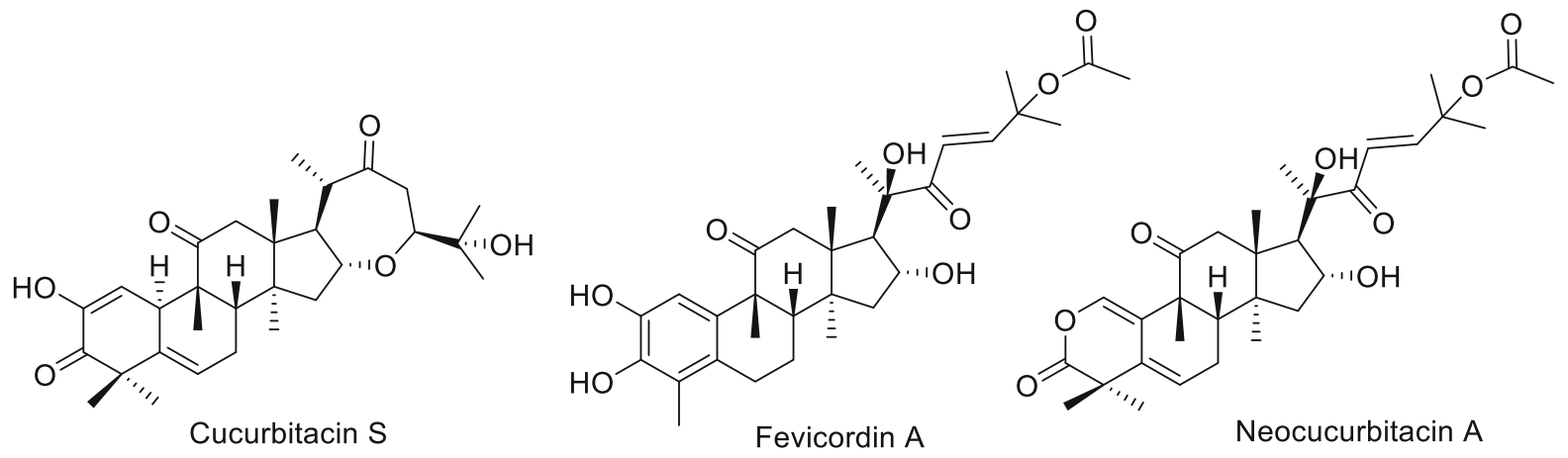

Fig. 3 Cucurbitacins with less common structures

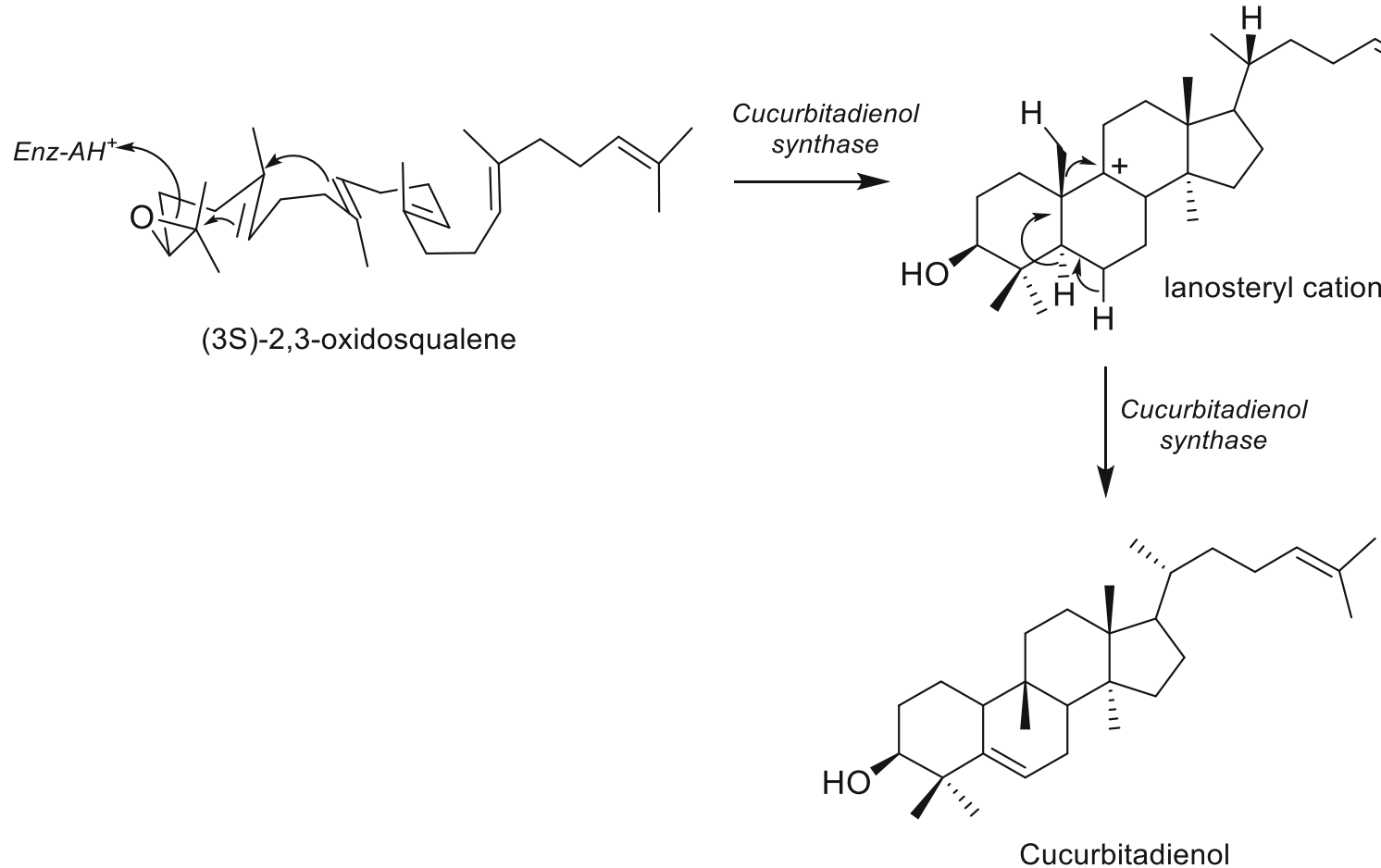

Fig. 4 Formation of cucurbitadienol from (3S)-2,3-oxidosqualene via chair-boat-chair conformation

cation stands as the branching point between cycloartenol and cucurbitadienol formation (Shibuya et al. 2004; Hu et al. 2020). Cucurbitadienol is the precursor of tetracyclic triterpenoids such as cucurbitacins and mogrosides. Further hydroxylation, oxidation, acetylation and glycosylation reactions will lead to the production of a large variety of cucurbitane-type triterpenes (Hu et al. 2020).

\section{Phytochemical constituents of Momordica balsamina}

The phytochemical study of the methanol extract of $M$. balsamina aerial parts, by our group, led to the isolation of several cucurbitane-type triterpenoids, most of them reported for the first time (Ramalhete et al. 2009a, b, 2010, 2011a, b). The compounds are herein divided in several groups, namely, the balsaminol set (1-9; Fig. 5), the balsaminoside (10-13; 


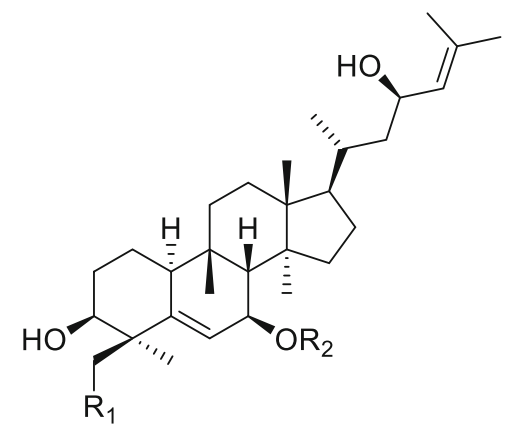

1: $\mathrm{R}_{1}=\mathrm{OH} ; \mathrm{R}_{2}=\mathrm{H}($ Balsaminol $\mathrm{A})$

2: $\mathrm{R}_{1}=\mathrm{OH} ; \mathrm{R}_{2}=\mathrm{CH}_{3}$ (Balsaminol $\left.\mathrm{B}\right)$

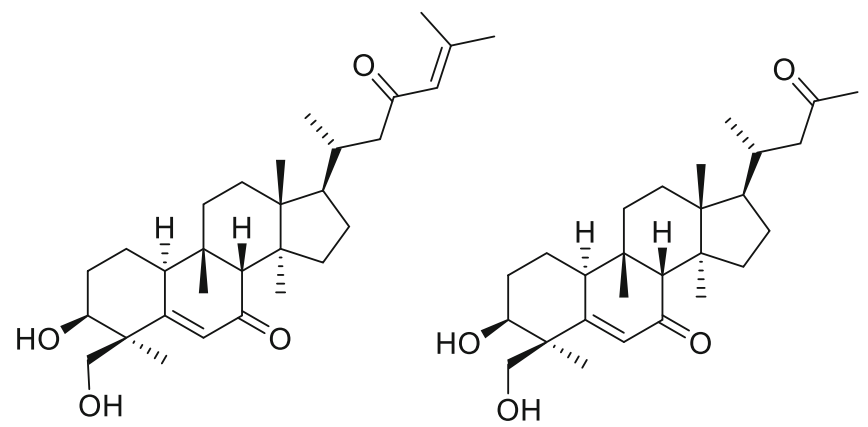

3 (Balsaminol C)

4 (Balsaminol D)

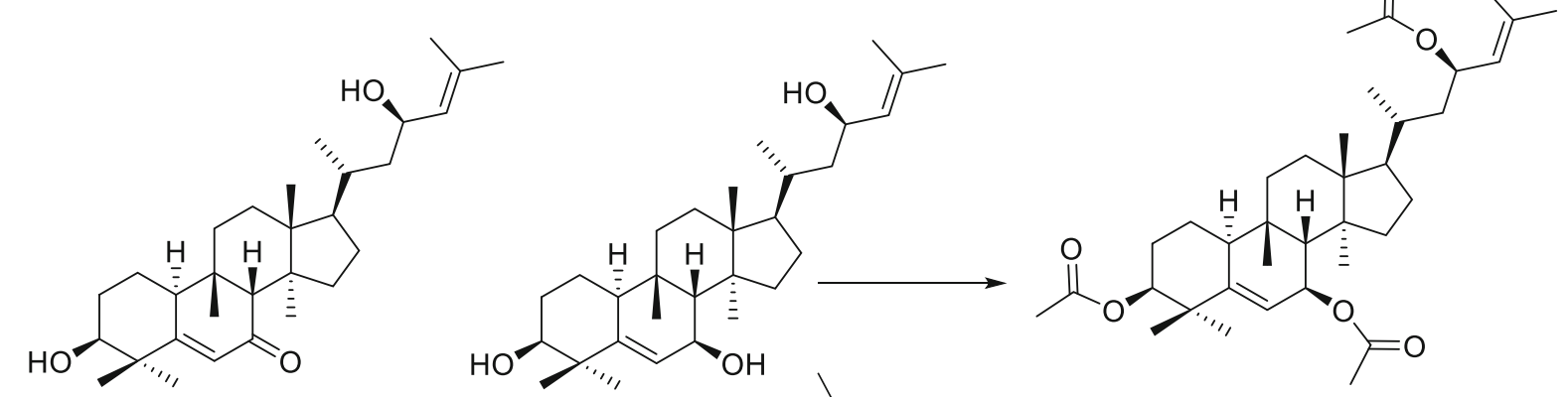

7 (triacetyl balsaminol F)

5 (Balsaminol E)

6 (Balsaminol F)
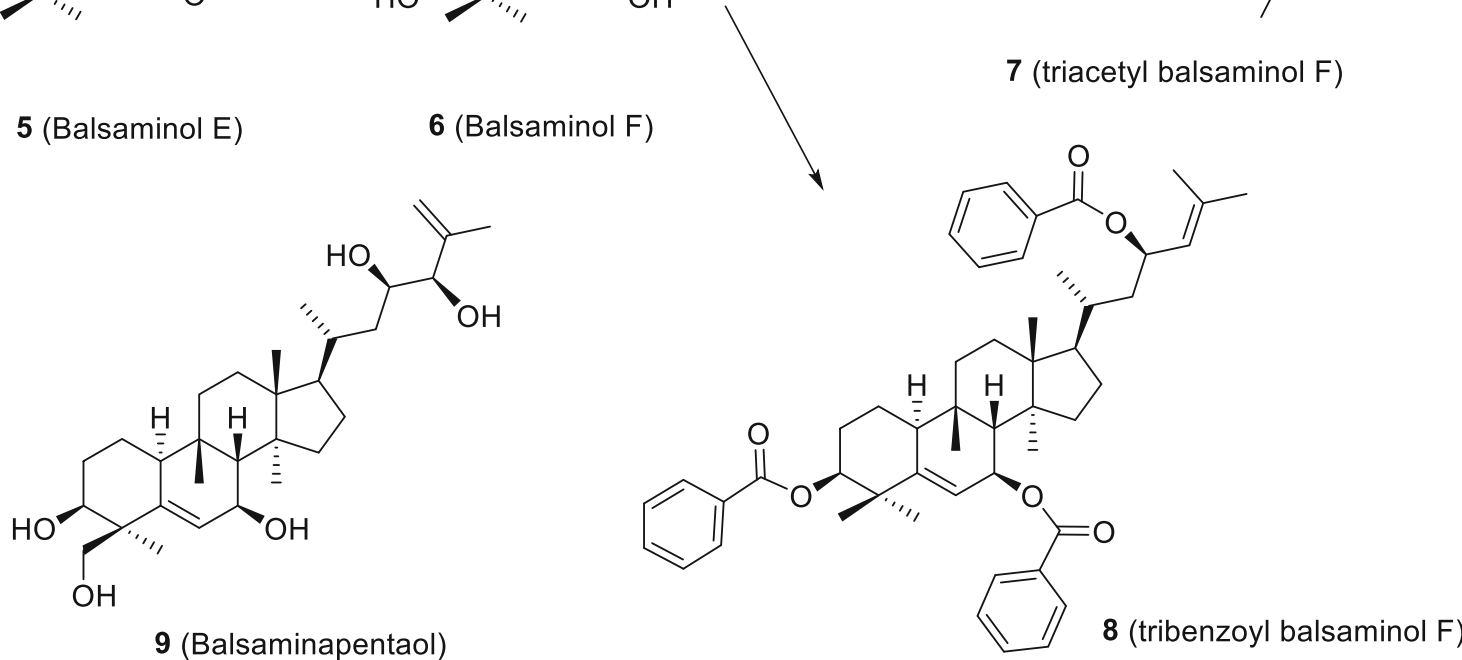

Fig. 5 Cucurbitacins from the balsaminol set. Compounds 1-6 and $\mathbf{9}$ were isolated from M. balsamina aerial parts (Ramalhete et al. 2009a, 2010). Compounds 7 and $\mathbf{8}$ were obtained by acylation reactions (Ramalhete et al. 2011a)

Fig. 6) and balsaminagenin sets (14-16; Fig. 6), the karavilagenin set (17-36; Fig. 7), and the cucurbalsaminol set (37-39; Fig. 8). Some of the new triterpenes have unusual oxidation patterns, reported for the first time in cucurbitacins from plant sources. Balsaminols A-D (1-4), balsaminagenins A (14) and B (15) and balsaminapentaol (9) have an unusual oxidation pattern at C-29, while cucurbalsaminols
A-C (37-39) share the presence of an uncommon hydroxyl group at C-12 (Ramalhete et al. 2009a, 2010, 2011b). Moreover, balsaminapentaol (9) has a 23,24-diol system coupled with an exocyclic double bond in the side chain, found for the first time in compounds with the cucurbitane skeleton (Ramalhete et al. 2009a). 


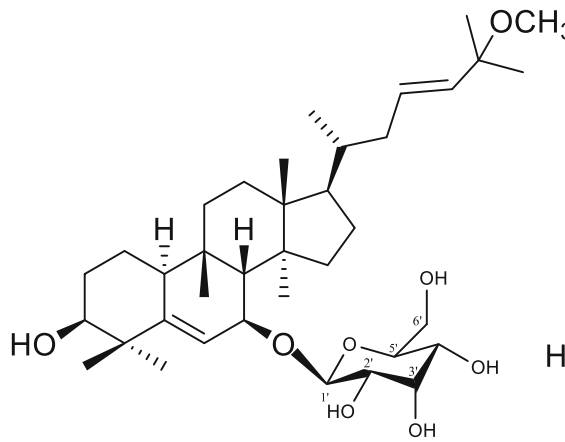

10 (Balsaminoside A)

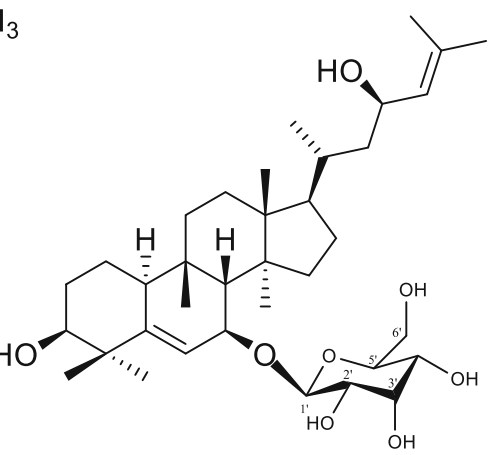

11 (Balsaminoside B)

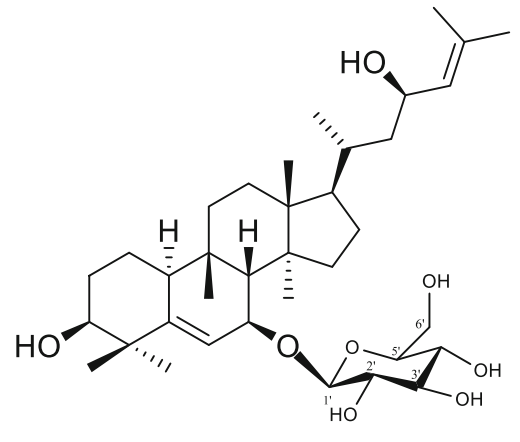

12 (Balsaminoside C)

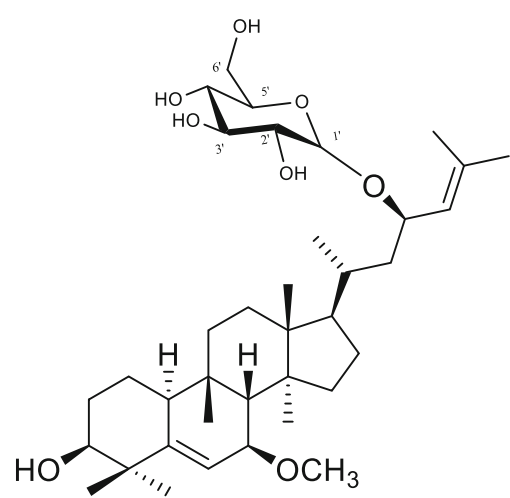

13 (Kuguaglycoside A)

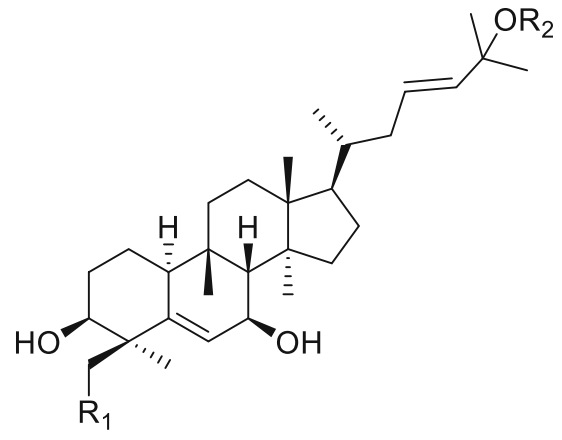

14: $\mathrm{R}_{1}=\mathrm{OH} ; \mathrm{R}=\mathrm{H}$ (Balsaminagenin $\left.\mathrm{A}\right)$

15: $\mathrm{R}_{1}=\mathrm{OH} ; \mathrm{R}=\mathrm{CH}_{3}$ (Balsaminagenin $\mathrm{B}$ )

16: $R_{1}=H ; R_{2}=H$ (Balsaminagenin $\left.C\right)$
Fig. 6 Cucurbitacins from the balsaminoside set (10-13) and balsaminagenin set (14-16) isolated from M. balsamina aerial parts (Ramalhete et al. 2009a, b, 2011a). Compounds $\mathbf{1 3}$ and $\mathbf{1 6}$

Cucurbalsaminones A-C (40-42), as referred above, are triterpenes with an unprecedented 5/6/3/6/ 5-fused pentacyclic scaffold (Fig. 8) (Mónico et al. 2019). A biosynthetic pathway for the new cucurbalsaminane skeleton was proposed by our group (Fig. 9). Thus, starting from a tetracyclic cucurbitane-type skeleton, with an $\alpha, \beta$-unsaturated carbonyl at $\mathrm{C}-7$, the main biochemical reactions would consist of a 1,2-alkyl shift through C-3/C-4 C-bond cleavage and the formation of a five-membered A ring through a Michael-type addition reaction. Further intramolecular alkylation of the resulting carbocation at C-4 would give rise to the new cyclopropane ring by connecting C-4 with C-6 (Mónico et al. 2019). were firstly isolated from $M$. charantia roots and stems, respectively (Chang et al. 2008; Chen et al. 2008)

In order to obtain a higher number of cucurbitacin derivatives, required for further biological and structure-activity relationship studies, balsaminol F (6) and karavilagenin C (17), isolated from M. balsamina in large amounts, were derivatized. Balsaminol F (6) was acylated affording two new ester derivatives named triacetyl balsaminol F (7) and tribenzoyl balsaminol F (8) (Fig. 5) (Ramalhete et al. 2011a). In turn, karavilagenin C (17) was acylated, using several alkanoyl anhydrides and aroyl chorides to obtain eighteen new ester derivatives named karavoates A-R (18-35, Fig. 7) (Ramalhete et al. 2011b). 

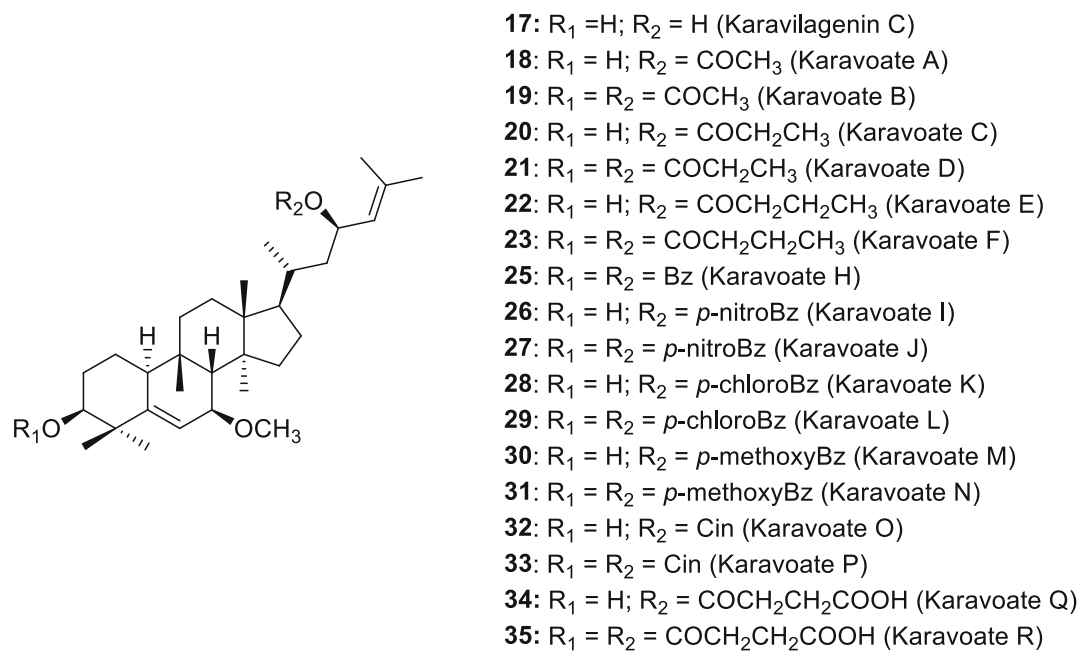

$\mathrm{Bz}=$<smiles>CCC(=O)c1ccccc1</smiles><smiles>CC(C)C(=O)/C=C/c1ccccc1</smiles>

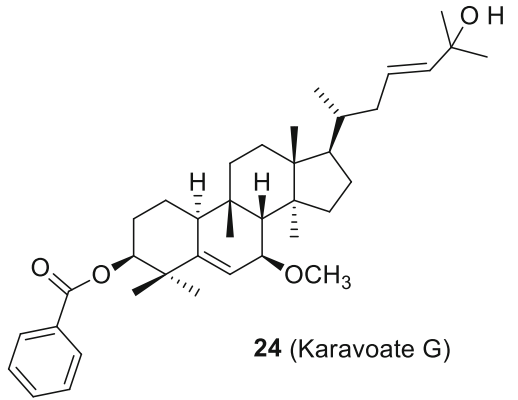

Fig. 7 Cucurbitacins from the karavilagenin set (17-36) (Ramalhete et al. 2009a, b). Compounds 18 - 35 were obtained by acylation reactions (Ramalhete et al. 2011b, 2016).

From the chloroform extract of M. balsamina fruits, three cucurbitacins (43-45, Fig. 10) were also isolated by other group (Kaushik et al. 2017).

Besides cucurbitane-type triterpenes, other compounds were also isolated from M. balsamina, namely a megastigmane-type nor-isoprenoid, identified as (+)-dehydrovomifoliol (46) (Ramalhete 2010) and five pimarane-type diterpenes (Tommasi et al. 1995) (Fig. 11).

Through ultra-high-performance liquid chromatography in tandem with quadrupole time-of-flight mass spectrometry (UHPLC/qTOFMS) analyses of the aqueous-methanol extract prepared from the leaves of $M$. balsamina, ten flavonols were also identified, including, quercetin-3,7-O- diglucoside (52),

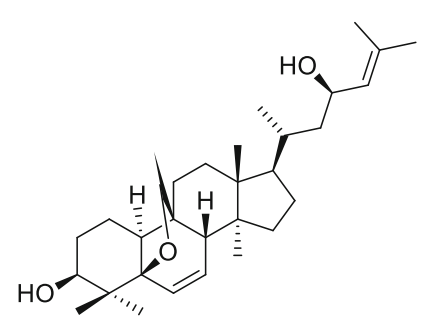

36 (Karavilagenin E)

Compounds $\mathbf{1 7}$ and $\mathbf{3 6}$ were firstly isolated from $M$. charantia fruits (Nakamura et al. 2006; Matsuda et al. 2007)

quercetin-3- $O$-sambubioside $(\mathbf{5 3})$, quercetin-3- $O$-rutinoside (54), quercetin-3- $O$-arabinoside-rhamnoside (55), quercetin-3,7-dirhamnoside (56), kaempferol-3$O$-rutinoside (57), kaempferol-3-O-glucoside (58), kaempferol-7- $O$-malonylglucoside (59), isorhamnetin-3-O-glucoside-7- $O$-arabinopyranoside (60) and isorhamnetin-3-O-glucoside (61) (Fig. 12) (Madala et al. 2016).

\section{Biological activities of Momordica balsamina constituents and derivatives}

As already mentioned, $M$. balsamina has a long history of folk medical usage in several countries. 


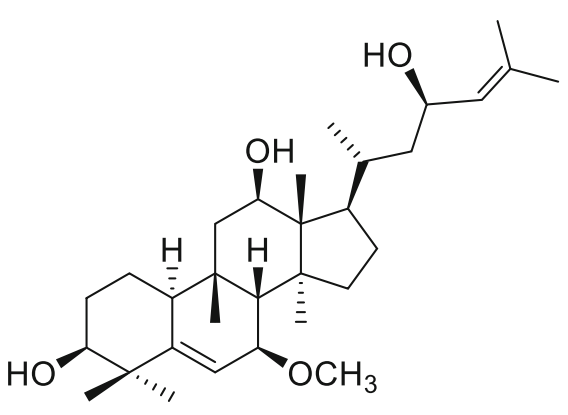

37 (Cucurbalsaminol A)

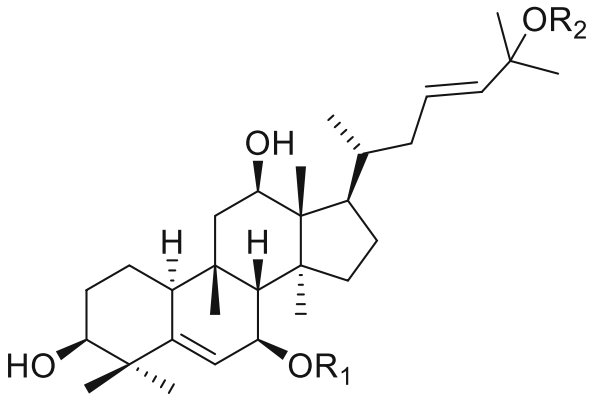

38: $\mathrm{R}_{1}=\mathrm{CH}_{3} ; \mathrm{R}_{2}=\mathrm{CH}_{3}$ (Cucurbalsaminol $\mathrm{B}$ )

39: $R_{1}=R_{2}=H($ Cucurbalsaminol $C$ )

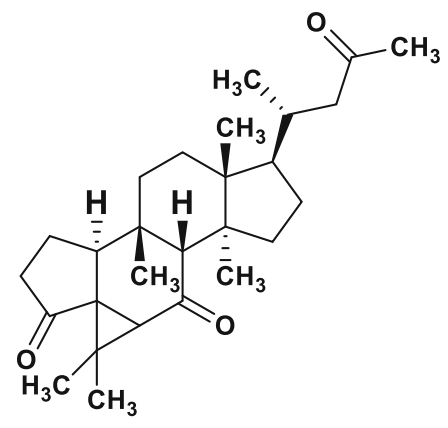

40 (Cucurbalsaminone A)

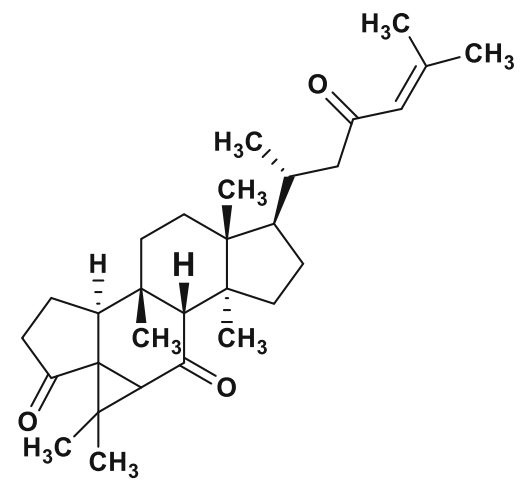

41 (Cucurbalsaminone B)

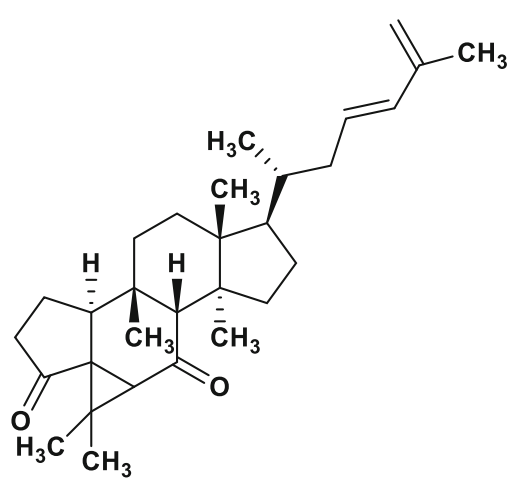

42 (Cucurbalsaminone C)

Fig. 8 Cucurbitacins from the cucurbalsaminol set (37-39) and cucurbalsaminane set (40-42) (Ramalhete et al. 2009a, 2011b; Mónico et al. 2019)

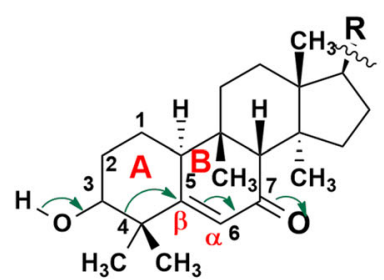

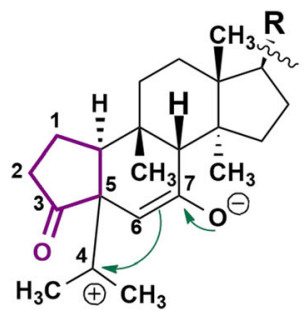

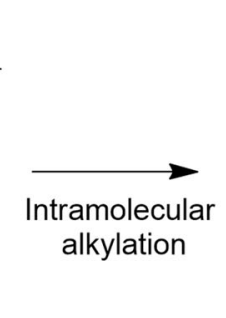

Fig. 9 Proposed biogenetic pathway for the cucurbalsaminane skeleton (Mónico et al. 2019)

Scientific studies conducted over the years have been claiming that many of the main constituents extracted from this plant, as well as some extracts, display a wide range of pharmacological activities (Fig. 13). In the next sections, the main therapeutic effects reported for its isolated compounds, semisynthetic derivatives 


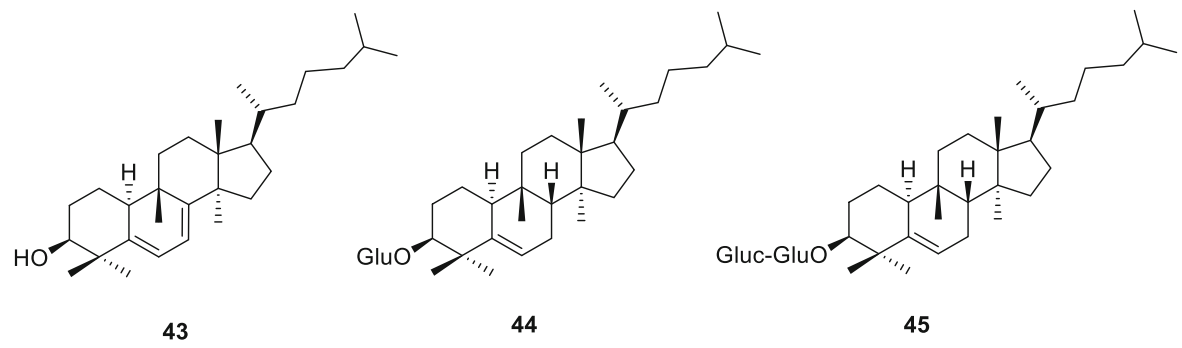

Fig. 10 Cucurbitacins isolated from M. balsamina fruits (Kaushik et al. 2017)

Fig. 11 Nor-isoprenoid (46) and pimarane-type diterpenes (47-51) isolated from M. balsamina aerial parts

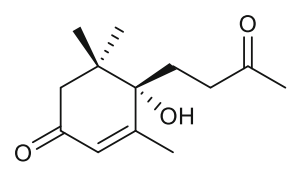

46

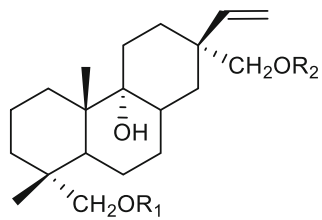

47: $\mathrm{R}_{1}=\mathrm{R}_{2}=\mathrm{H}$

48: $R_{1}=R_{2}=A c$

49: $R_{1}=A c, R_{2}=H$

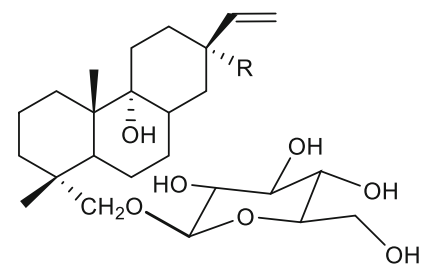

50: $\mathrm{R}=\mathrm{CH}_{2} \mathrm{OH}$

51: $\mathrm{R}=\mathrm{COOH}$ and extracts in in vitro or/and in vivo studies will be reviewed in detail.

\section{Anticancer activity. Multidrug resistance reversion}

Cancer burden is dramatically increasing worldwide owing to several factors, namely population ageing. According to the World Health Organization (WHOnoncomunicable diseases team 2021), cancer is the second main cause of death globally. Multidrug resistance (MDR) is the foremost impediment for successful chemotherapy in cancer treatment (Gottesman et al. 2002).

The in vitro and in vivo anticancer activity of cucurbitacins, in several cancer models, has been largely reported, being the most studied cucurbitacins B (62), E (63) and I (64) (Fig. 14). They were able to induce the apoptotic pathways and block cell cycle by inhibiting cyclins. Their ability to increase autophagy and to inhibit the invasion and migration of cancer cells as well their synergistic interaction when combined with anticancer drugs, in several cancer cells, have also been reported (Ateba et al. 2018; Jing et al. 2020). Herein, we will focus on the ability of cucurbitane-type triterpenoids as multidrug resistance reversers in cancer.

MDR can result from several factors and can involve several mechanisms simultaneously (Gottesman et al. 2002, 2016). One of the most significant mechanisms responsible for MDR is the overexpression of ATP-binding cassette (ABC) transporter proteins, which pump out of the cells anticancer drugs, inhibiting them from reaching therapeutic levels within cancer cells. P-glycoprotein (P-gp/ $\mathrm{ABCB} 1$ ), breast cancer resistance protein (BCRP/ $\mathrm{ABCG} 2$ ), and multidrug resistance protein 1 (MRP1/ $\mathrm{ABCC} 1)$ are the three major efflux proteins implicated in MDR. P-gp, the most important and known ABC transporter and characterized by a broad subtract spectrum, is able to efflux a large number of anticancer drugs. Among the strategies that have been proposed to overcome P-gp-mediated MDR, the most consensual is the development of P-gp inhibitors able to reverse MDR, when co-administered with an anticancer drug, by inhibiting P-gp efflux-activity and 
<smiles>O=c1c(O[C@@H]2O[C@H](CO)[C@@H](O)[C@H](O)[C@H]2O)c(-c2ccc(O)c(O)c2)oc2cc(O[C@@H]3O[C@H](CO)[C@@H](O)[C@H](O)[C@H]3O)cc(O)c12</smiles><smiles>O=c1c(O[C@@H]2OC(CO)[C@@H](O)[C@H](O)[C@H]2O[C@H]2OC[C@@H](O)[C@H](O)[C@H]2O)c(-c2ccc(O)c(O)c2)oc2cc(O)cc(O)c12</smiles><smiles>[R]c1cc(-c2oc3cc(O)cc(O)c3c(=O)c2O[C@@H]2O[C@H](CO[C@H]3O[C@H](C)[C@@H](O)[C@H](O)[C@H]3O)[C@@H](O)[C@H](O)[C@H]2O)ccc1O</smiles><smiles>C[C@@H]1O[C@H](O[C@H]2[C@@H](O)[C@@H](CO)O[C@@H]2Oc2c(-c3ccc(O)c(O)c3)oc3cc(O)cc(O)c3c2=O)[C@H](O)[C@@H](O)[C@H]1O</smiles><smiles>C[C@@H]1O[C@H](Oc2cc(O)c3c(=O)c(O[C@@H]4O[C@H](C)[C@@H](O)[C@H](O)[C@H]4O)c(-c4ccc(O)c(O)c4)oc3c2)[C@H](O)[C@@H](O)[C@@H]1O</smiles><smiles>[R2]Oc1ccc(-c2oc3cc(O)cc(O)c3c(=O)c2O[C@@H]2O[C@H](CO)[C@@H](O)[C@H](O)[C@H]2O)cc1[R2]</smiles>

58: $R_{1}=R_{2}=H$

61: $\mathrm{R}_{1}=\mathrm{CH}_{3} ; \mathrm{R}_{2}=\mathrm{OH}$<smiles>O=C(O)CC(=O)OC[C@H]1O[C@@H](Oc2cc(O)c3c(=O)c(O)c(-c4ccc(O)cc4)oc3c2)[C@H](O)[C@@H](O)[C@@H]1O</smiles>

59<smiles>COc1ccc(-c2oc3cc(O[C@@H]4OC[C@@H](O)[C@H](O)[C@H]4O)cc(O)c3c(=O)c2O[C@@H]2O[C@H](CO)[C@@H](O)[C@H](O)[C@H]2O)cc1O</smiles>

Fig. 12 Flavonols identified in M. balsamina leaves

subsequently restoring drug accumulation. Nevertheless, in spite of the great in vitro success, at present, there is no P-gp inhibitor in clinical use (Stefan 2019).

The development of collateral sensitizing (CS) agents is also among the most promising approaches to overcome MDR (Callaghan et al. 2014; Szakács et al. 2014). According to the concept that is behind this strategy, currently considered a strong anti-MDR approach, changes of cancer cells responsible for MDR can at the same time generate vulnerabilities that make drug-resistant cells more sensitive to certain agents than the corresponding sensitive cells. The mechanism of CS agents is not clear yet. It is believed to be correlated with the overexpression of P-gp, MRP1 or BCRP in MDR cancer cells. Thus, it represents a new approach to avoid ABC-transporters-mediated MDR by developing selective compounds against resistant-phenotypes able to prevent MDR by co-administration during chemotherapy or re-sensitize resistant tumors by killing MDR cells selectively (Gottesman et al. 2016). In P-gp-overexpressing cancer cells, CS agents are thought to act by different biochemical mechanisms. In case of cancer cells overexpressing MRP1, there are several studies 


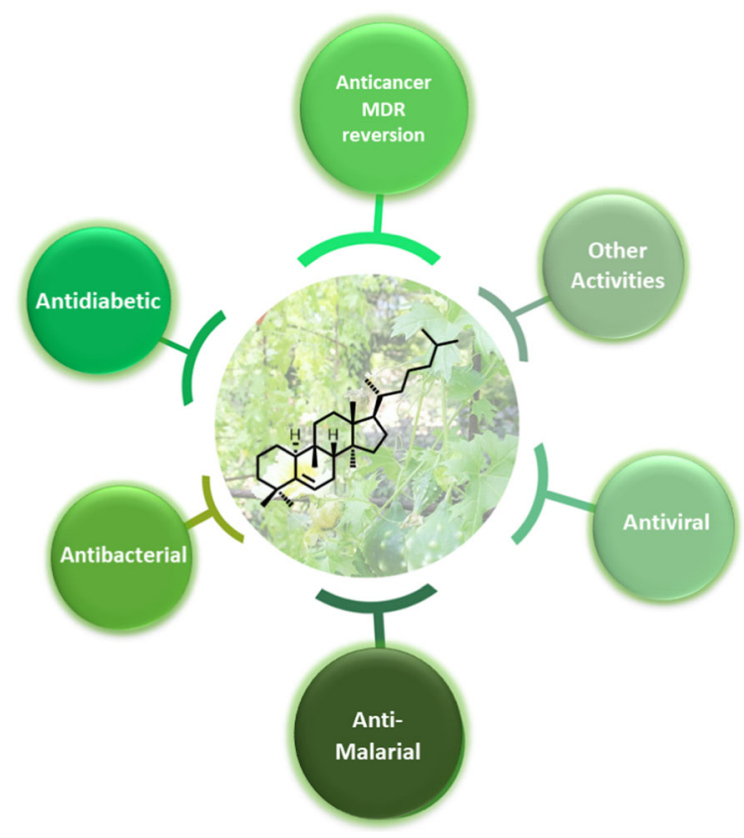

Fig. 13 Main pharmacological activities reported for $M$. balsamina constituents, hemi-synthetic derivatives and plant extracts

providing evidence that they mostly act by stimulating the efflux of glutathione by this transporter protein, and consequently altering redox balance and, in this way, selectively triggering the apoptotic pathways of MDR cells (Szakács et al. 2014).

\section{P-glycoprotein modulation activity}

The set of natural cucurbitane triterpenes 1-6, 9, 1017, and 36-39, isolated from M. balsamina, was evaluated for their ability as P-gp inhibitors in $A B C B 1$ transfected mouse T-lymphoma (L5178Y-MDR) cells, by flow cytometry, using the rhodamine- 123 exclusion assay, a fluorescent P-gp substrate (Ramalhete et al. 2009a, b, 2016; Ferreira et al. 2014). In this functional assay, the inhibitory ability of compounds is assessed, as fluorescence activity ratios (FAR), by comparing the accumulation of rhodamine-123 in resistant (MDR) and sensitive cells (parental cells, PAR) and compounds with FAR $>10$ are considered strong P-gp inhibitors. In this set, most of the compounds have shown strong P-gp efflux inhibitory activity at $20 \mu \mathrm{M}$ (FAR values ranging from 19.8-198.9). Balsaminol C (3) showed the highest inhibitory activity $($ FAR $=198.9)$, followed by balsaminagenin B (15), and balsaminoside A (10) $($ FAR $=104.2$ and 89.4, respectively), having a manifold activity when compared with positive control verapamil $(\mathrm{FAR} \cong 8$ at $22 \mu \mathrm{M})$. Nevertheless, karavilagenin $\mathrm{C}(\mathbf{1 7})$ was the most active at $2 \mu \mathrm{M}$ (FAR $=42.1$ and 46 , at $2 \mu \mathrm{M}$ and $20 \mu \mathrm{M}$, respectively), and showed to be still active, in a dose dependent mode, at lower concentrations (Table 2).

Cucurbalsaminones $\mathrm{A}-\mathrm{C}$ (40-42), sharing the new pentacyclic cucurbalsaminane scaffold, were also assessed for their ability to inhibit the efflux pump activity of P-glycoprotein, using the same cell model (Mónico et al. 2019). Interestingly, the three compounds (40-42) exhibited strong activity at $2 \mu \mathrm{M}$ (FAR $=14.2,76.9$, and 62.2, respectively) and compounds $\mathbf{4 1}$ and $\mathbf{4 2}$ were still active at nanomolar level (FAR > 3), while compound 40, bearing a shorter side chain, showed no significant activity at this concentration $(\mathrm{FAR}=1.4$ at $0.2 \mu \mathrm{M})$, thus corroborating the importance of the structural features of the side chain in the inhibitory activity.

Based on the previous results, aiming at obtaining structure-activity relationships (SAR), the acyl

Fig. 14 Cucurbitacins B (62), E (63) and I (64)

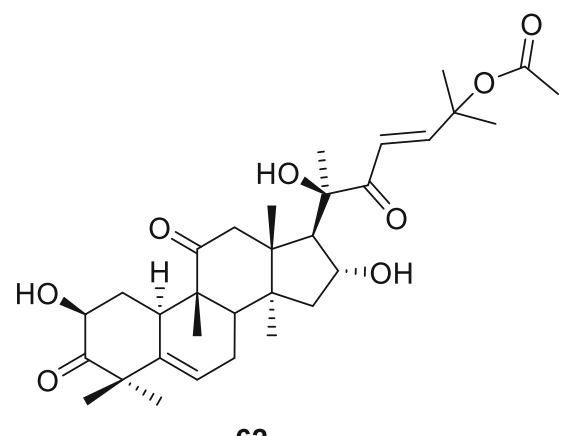

62

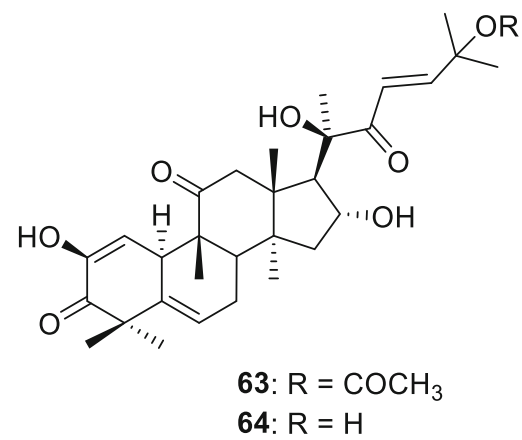

64: $\mathrm{R}=\mathrm{H}$ 
Table 2 P-gp inhibitory activity of the natural compounds $\mathbf{3}$, $\mathbf{1 0}, \mathbf{1 5}, \mathbf{1 7}, \mathbf{4 0 - 4 2}$, and the acyl derivatives $7, \mathbf{1 8}-\mathbf{2 0}$, and 22 in human $A B C B 1$-gene-transfected mouse lymphoma cells (Ramalhete et al. 2009b, 2016) (Mónico et al. 2019)

\begin{tabular}{|c|c|c|}
\hline Compounds & Conc. $\mu \mathrm{M}$ & $\mathrm{FAR}^{\mathrm{a}}$ \\
\hline Verapamil & 22 & 7.4 \\
\hline \multirow[t]{2}{*}{ Balsaminol C (3) } & 2 & 2.9 \\
\hline & 20 & 198.9 \\
\hline \multirow[t]{2}{*}{ Balsaminagenin B (15) } & 2 & 5.98 \\
\hline & 20 & 104.2 \\
\hline \multirow[t]{2}{*}{ Balsaminoside A (10) } & 2 & 1.45 \\
\hline & 20 & 89.4 \\
\hline \multirow[t]{4}{*}{ Karavilagenin C (17) } & 0.5 & 1.5 \\
\hline & 1 & 15.0 \\
\hline & 2 & 42.1 \\
\hline & 20 & 46.0 \\
\hline \multirow[t]{3}{*}{ Cucurbalsaminone A (40) } & 0.2 & 1.4 \\
\hline & 2 & 14.2 \\
\hline & 20 & 87.5 \\
\hline \multirow[t]{3}{*}{ Cucurbalsaminone B (41) } & 0.2 & 5.9 \\
\hline & 2 & 76.9 \\
\hline & 20 & 105.5 \\
\hline \multirow[t]{3}{*}{ Cucurbalsaminone C (42) } & 0.2 & 3.1 \\
\hline & 2 & 62.2 \\
\hline & 20 & 117.7 \\
\hline \multirow[t]{2}{*}{ Triacetylbalsaminol F (7) } & 2 & 3.0 \\
\hline & 20 & 15.0 \\
\hline \multirow[t]{2}{*}{ Karavoate A (18) } & 2 & 35.2 \\
\hline & 20 & 34.2 \\
\hline \multirow[t]{2}{*}{ Karavoate B (19) } & 2 & 5.7 \\
\hline & 20 & 37.5 \\
\hline \multirow[t]{2}{*}{ Karavoate C (20) } & 2 & 1.7 \\
\hline & 20 & 40.6 \\
\hline \multirow[t]{2}{*}{ Karavoate E (22) } & 2 & 1.0 \\
\hline & 20 & 21.7 \\
\hline
\end{tabular}

${ }^{\mathrm{a}} \mathrm{FAR}$-Fluorescence activity ratio: accumulation ratio of rhodamine 123 between resistant (MDR) and sensitive (PAR) cells. FAR $>1$ means the compound is active; FAR $>10$ means strong P-gp modulation

$F A R=\frac{F L-1 M D R \text { treated } / F L-1 M D R \text { untreated }}{F L-1 \text { PAR treated } / F L-1 \text { PAR untreated }}$

derivatives 18-35 of karavilagenin C (17), a major compound, and two triacyl derivatives (7 and 8) of balsaminol F (6) were also assessed for their ability as
P-gp inhibitors, in the same cell lines. In this set of karavilagenin $\mathrm{C}$ (17) derivatives (18-35), a significant decrease of activity was observed when compared with the parent compound. The most active derivative was the monoester karavoate A (18) (FAR = 35.2 and 34.2 , at 2 and $20 \mu \mathrm{M}$, respectively), while karavoates $\mathrm{B}, \mathrm{C}$ and $\mathrm{E}(\mathbf{1 9}, \mathbf{2 0}$ and 22) were found to be strong P-gp (FAR > 10) inhibitors only at $20 \mu \mathrm{M}$. At this concentration, triacetylbalsaminol F (7) was also able to strongly inhibit P-gp efflux activity, whereas the derivative of balsaminol $F(6)$, bearing a tribenzoyl moiety (8), was inactive or barely active (Table 2). Regarding the decrease of activity of karavilagenin C (17) esters, it was concluded that the presence of both hydroxyl groups at $\mathrm{C}-3$ of ring $\mathrm{A}$, of the tetracyclic nucleus, and at $\mathrm{C}-23$, in the side chain, were essential for the activity. It was inferred that an optimal $\log$ $P$ value was associated with the activity. Thus, in spite of the general assumption that aromatic groups are connected with higher inhibition of P-gp activity, in these compounds due to the increase of lipophilicity, they were unfavorable. In relation to the substitution pattern of the triterpenic scaffold, while the presence of a methoxyl group at C-7 was thought to be important for the activity, an extra hydroxyl group at C-12 decreased the activity. The side chain structure also appeared to affect the inhibitory activity, namely the substituent at C-25 and compounds with shorter side chains were also less active.

In chemosensitivity assays, some representative inhibitors (1-3, 5, 10, 13, 15-18, 36, 38, and 39) were evaluated, in resistant mouse lymphoma cells, for their interaction with the anticancer drug doxorubicin, a P-gp subtract (Ramalhete et al. 2009b, 2016). The type of interaction was assessed by their fractional inhibitory index (FIX) (Eliopoulos and Moellering 1991) or combination index (CI) values (Chou 2006, 2010). Apart from compound 13, that was almost additive, all the remaining compounds interacted synergistically with doxorubicin (FIX $<0.5$ / $\mathrm{CI}<1$ ), restoring its cytotoxicity hampered by the efflux-pump activity of P-gp. Interestingly, the strongest P-gp inhibitors at $20 \mu \mathrm{M}$, in the rhodamine-123 exclusion assay, balsaminol C (3) (FAR = 198.9; $\mathrm{CI}=0.27)$ and balsaminagenin $\mathrm{B}(\mathbf{1 5})(\mathrm{FAR}=$ 104.2; FIX $=0.18$ ), exhibited the lowest FIX/CI values, thus substantiating their activity as MDR reversers. 
Collateral sensitivity ability

Aiming at finding compounds with more than one antiMDR mechanism, twenty eight of the above mentioned cucurbitane-type triterpenoids, isolated from M. balsamina or obtained through acylation of karavilagenin C (17), were assessed for their capability as collateral sensitivity agents on gastric (EPG85257), pancreatic (EPP85-181) and colon (HT-29) cancer cell models. In relation to each cell model, two drug-resistant sublines, selected against daunorubicin (RDB) or mitoxantrone (RNOV) were used (Ramalhete et al. 2018). For assessing the collateral sensitivity effect, the relative resistance ratio $\left(\mathrm{RR}=\mathrm{IC}_{50 \text { (resistant) }} / \mathrm{IC}_{50 \text { (parental) }}\right)$ was determined for each compound. Values of $\mathrm{RR}<1$ mean that the compounds are more effective against MDR cells then parental cells, and those with $\mathrm{RR} \leq 0.50$ are considered to be collateral sensitivity agents (Hall et al. 2009).

Most of the compounds showed higher sensitivity against MDR sublines $(\mathrm{RR}<1)$, mainly on resistant gastric and colon cancer cells. Against resistant gastric cell lines, the best results were found for balsaminol $\mathrm{F}$ (6) $\left(\mathrm{IC}_{50}=6.2 \mu \mathrm{M} ; \mathrm{RR}=0.43\right)$ and karavilagenin $\mathrm{C}$ (17) $\left(\mathrm{IC}_{50}=2.5 \mu \mathrm{M} ; \mathrm{RR}=0.32\right)$ against the gastric EPG85-257 RDB subline, exhibiting both CS effect together with high antiproliferative effect, which was similar to those found for the positive controls. Likewise, in the gastric EPG85-257 RNOV subline, CS effect concomitant with strong antiproliferative activity was also found for balsaminol $\mathrm{F}(\mathbf{6})\left(\mathrm{IC}_{50-}\right.$ $=7.2 \mu \mathrm{M}, \mathrm{RR}=0.50)$ and balsaminoside $\mathrm{A}(\mathbf{1 0})$ $\left(\mathrm{IC}_{50}=4.5 \mu \mathrm{M}, \mathrm{RR}=0.47\right)($ Table 3$)$.

Regarding colon cancer cells lines, the most selective compounds, against both resistant variants, were also karavilagenin C (17), (EPG85-257 RDB, $\mathrm{IC}_{50}=6.8 \mu \mathrm{M}, \mathrm{RR}=0.49 ;$ EPG85-257 RNOV, $\mathrm{IC}_{50-}$ $=6.7 \mu \mathrm{M} ; \mathrm{RR}=0.49)$ and the acyl derivatives karavoates A (18), C (20) and E (22) (EPG85-257 $\mathrm{RDB}, \mathrm{IC}_{50}=3.1-7.1 \mu \mathrm{M} ; \mathrm{RR}=0.39-0.51$; EPG85$\left.257 \mathrm{RNOV} ; \mathrm{IC}_{50}=2.3-4.9 \mu \mathrm{M}, \mathrm{RR}=0.26-0.36\right)$. In case of MDR pancreatic cell sublines, karavilagenin C (17) $\left(\mathrm{IC}_{50}=9.8 \mu \mathrm{M} ; \mathrm{RR}=0.51\right)$ and balsaminol $\mathrm{F}(\mathbf{6})$ $\left(\mathrm{IC}_{50}=8.5 \mu \mathrm{M} ; \mathrm{RR}=0.55\right)$ were the most selective against the pancreatic EPP85-181RDB cells (Table 3).

Although no statistical correlation between the antiproliferative activity and lipophilicity was found, compounds with high $\log P$ values $(\geq 8.5)$ have not shown antiproliferative effect $\left(\mathrm{IC}_{50}>100 \mu \mathrm{M}\right)$ (Table 3).

As mentioned, these compounds were also found to be strong P-gp modulators. This dual activity, as P-gp modulators and MDR-selective antiproliferative

Table 3 Antiproliferative activity of compounds 6, 10, 17, 18, 20 and 22 in gastric (EPG85-257), pancreatic (EPP85-181) and colon (HT-29) cancer cell models (Ramalhete et al. 2018)

\begin{tabular}{|c|c|c|c|c|c|}
\hline Compound & $\begin{array}{l}\mathrm{IC}_{50}(\mu \mathrm{M}) \pm \mathrm{SD} \\
\mathrm{EPG85-257P}\end{array}$ & $\begin{array}{l}\mathrm{IC}_{50}(\mu \mathrm{M}) \pm \mathrm{SD} \\
\text { EPG85-257RDB }\end{array}$ & $\mathrm{RR}^{1}$ & $\begin{array}{l}\mathrm{IC}_{50}(\mu \mathrm{M}) \pm \mathrm{SD} \\
\text { EPG85-257RNOV }\end{array}$ & $\mathrm{RR}^{1}$ \\
\hline Balsaminol F (6) & $14.4 \pm 3.8$ & $6.2 \pm 0.4$ & 0.43 & $7.2 \pm 0.7$ & 0.50 \\
\hline Balsaminoside A (10) & $9.5 \pm 2.8$ & $>100$ & $>10.52$ & $4.5 \pm 2.5$ & 0.47 \\
\hline \multirow[t]{2}{*}{ Karavilagenin C (17) } & $7.9 \pm 0.4$ & $2.5 \pm 0.4$ & 0.32 & $6.6 \pm 0.56$ & 0.84 \\
\hline & HT-29P & HT-29RDB & & HT-29RNOV & \\
\hline Karavilagenin C (17) & $13.8 \pm 0.6$ & $6.8 \pm 1.4$ & 0.49 & $6.7 \pm 0.8$ & 0.49 \\
\hline Karavoate A (18) & $7.9 \pm 3.1$ & $3.1 \pm 1.2$ & 0.39 & $2.3 \pm 0.0$ & 0.29 \\
\hline Karavoate C (20) & $13.8 \pm 2.7$ & $7.1 \pm 0.0$ & 0.51 & $4.9 \pm 0.6$ & 0.36 \\
\hline \multirow[t]{2}{*}{ Karavoate E (22) } & $15.4 \pm 0.5$ & $6.9 \pm 0.2$ & 0.45 & $4.0 \pm 1.1$ & 0.26 \\
\hline & EPP85-181P & EPP85-181RDB & & EPP85-181RNOV & \\
\hline Balsaminol F (6) & $15.4 \pm 3.2$ & $8.5 \pm 0.9$ & 0.55 & $11.7 \pm 1.8$ & 0.76 \\
\hline Karavilagenin C (17) & $6.7 \pm 0.2$ & $6.8 \pm 0.9$ & 1.00 & $6.7 \pm 2.3$ & 1.00 \\
\hline
\end{tabular}

${ }^{1} \mathrm{RR}$ (relative resistance ratio) $=\mathrm{IC}_{50 \text { (resistant) }} / \mathrm{IC}_{50 \text { (parental) }}$ ). $\mathrm{RR}<1:$ MDR-selective antiproliferative effect; $\mathrm{RR} \leq 0.5$ : collateral sensitivity effect. 
compounds, could be important for tackling MDR, thus underlining their potential as anti-MDR lead compounds.

\section{Antimalarial and schistosomicidal activities}

Human parasitic diseases continue to represent a threat on a global scale, especially among the poorest countries in the world. Malaria, caused by unicellular parasites of the genus Plasmodium, which is transmitted by the bite of the Anopheles mosquito, is one of the most devastating and widespread tropical diseases leading to high morbidity and mortality. Nevertheless, good news have come from the WHO Malaria Report 2020 , which presented a $60 \%$ reduction of global malaria mortality, when comparing data from 2000 to 2019, mainly due to increased investment in malaria programs and research (WHO 2020a). This tendency is also evident on children under 5 years old, as the percentage of total malaria deaths was $84 \%$ in 2000 and $67 \%$ in 2019 (WHO 2020a). P. falciparum, $P$. vivax, $P$. malariae, $P$. knowlesi, and $P$. ovale are the main species causing human malaria. Among these, $P$. falciparum is considered the most dangerous, being recognized as the one with the highest rates of complications and mortality. Nevertheless, in spite of the encouraging WHO Malaria Report 2020, the treatment of the disease remains a threat. In fact, drug options are scarce and highly challenged by the emergence of resistant strains (Madhav and Hoda 2021). The same is observed for insecticides used to eliminate the vector Anopheles (Minetti et al. 2020), and the available vaccines showed a low efficacy as stated in recently reviewed literature (Pance 2020). The oldest antimalarial drug was the alkaloid quinine, firstly isolated in 1820 from Cinchona bark. It stayed the mainstream drug till the 1920s (Achan et al. 2011), whereas its synthetic derivatives, namely chloroquine, were widely used from the 1940s up to the 1990s as the mainstay of malaria therapy worldwide, until the spread of chloroquine resistant Plasmodium strains (Coban 2020). Currently, the treatment with artemisinin-based combination therapies, a sesquiterpene lactone firstly isolated from Artemisia аппиа, is the most used in almost all endemic malaria regions (WHO 2021a). However, artemisinin-based combination therapies are quickly failing across South-East Asia due to the identification of locally Plasmodium resistance strains (Pasupureddy et al. 2019; Coban 2020).

M. balsamina is widely used to treat fever symptoms associated with malaria in some African countries, namely Mozambique (Bandeira et al. 2001). In in vitro studies, the dichloromethane-methanol extracts obtained from different parts of M. balsamina showed significant antiplasmodial activity against $P$. falciparum $\mathrm{D} 10$ strain $\left(\mathrm{IC}_{50}\right.$ ranging from 5 to $18 \mu \mathrm{g} /$ $\mathrm{mL}$ ) (Clarkson et al. 2004), according to literature criteria (Cos et al. 2006). Further in vivo studies corroborated these results, being observed a 52 and $80 \%$ reduction of parasitaemia in mice infected with $P$. vinckei, after intraperitoneal administration of $M$. balsamina methanol extract alone or in combination with other plant extracts $(100 \mathrm{mg} / \mathrm{kg} / \mathrm{day}$, each), namely Sesamum alatum and Limeum pterocarpum both used in Niger traditional medicine mixed with $M$. balsamina to treat malaria fever (artemisinin $10 \mathrm{mg}$ / $\mathrm{kg} /$ day was used as positive control with a parasitaemia reduction of 79\%) (Benoit-Vical et al. 2006).

$M$. balsamina was also included by our group in an antimalarial screening of fifty eight crude extracts from fifteen plants traditionally used against malaria and fever, mostly from Southern African countries (Ramalhete et al. 2008). The best results were obtained for the ethyl acetate extract of the aerial parts of $M$. balsamina, which was found to be highly active $\left(\mathrm{IC}_{50}\right.$ of $1 \mu \mathrm{g} / \mathrm{mL}$ ) against chloroquine-sensitive $P$. falciparum strain (3D7) (Cos et al. 2006; Ramalhete et al. 2008; Ramalhete 2010). These results corroborated the previous studies and led us to a bioguided fractionation yielding several cucurbitacins (Ramalhete et al. 2010, 2011a, b), which were evaluated for their antimalarial activity, against chloroquine-sensitive (3D7) and resistant (Dd2) P. falciparum strains, in the erythrocyte stage of the parasite. The antimalarial activity was classified according to following criteria: $\mathrm{IC}_{50} \leq 1 \mu \mathrm{M}$, excellent; $1<\mathrm{IC}_{50} \leq 10 \mu \mathrm{M}$, good; $10<\mathrm{IC}_{50} \leq 30 \mu \mathrm{M}$, moderate; and $\mathrm{IC}_{50}>30 \mu \mathrm{M}$ weak/inactive (Ramalhete et al. 2011a). In this way, and comparing with the positive control used in these assays (chloroquine, $\mathrm{IC}_{50}=0.016$ and $0.2 \mu \mathrm{M}$, for 3D7 and Dd2, respectively), from the nineteen natural compounds isolated from M. balsamina (1-6, 9-17, 36-39), the cucurbitane glycosides, bearing a sugar unit at $\mathrm{C}-7$, were the most effective against both strains (Table 4), namely kuguaglycoside $\mathrm{A}\left(\mathbf{1 3}, \mathrm{IC}_{50}=3.9\right.$ and $4.7 \mu \mathrm{M}$, for $3 \mathrm{D} 7$ and $\mathrm{Dd} 2$, respectively), 
Table 4 Relevant antimalarial compounds obtained from Momordica balsamina

\begin{tabular}{|c|c|c|c|c|c|c|c|}
\hline \multirow[t]{2}{*}{ Compounds } & \multicolumn{2}{|c|}{$\begin{array}{l}\mathrm{IC}_{50}(\mu \mathrm{M}) \text { Erythrocytes } \\
\text { in vitro assay } P \text {. falciparum } \\
\text { strain }\end{array}$} & \multicolumn{3}{|c|}{$\begin{array}{l}\% \text { parasitaemia inhibition Hepatic } \\
\text { cells in vitro assay }\end{array}$} & \multicolumn{2}{|c|}{$\begin{array}{l}\% \text { parasitaemia inhibition } \\
\text { In vivo assay Oral } \\
\text { administration }\end{array}$} \\
\hline & $3 \mathrm{D} 7$ & $\mathrm{Dd} 2$ & $15 \mu \mathrm{M}$ & $5 \mu \mathrm{M}$ & $1 \mu \mathrm{M}$ & $50^{*}$ & $25^{*}$ \\
\hline Balsaminol F (6) & 18.0 & 20.0 & 97 & 31.4 & 14.7 & - & - \\
\hline Triacetylbalsaminol F (7) & 0.8 & 0.4 & 98.0 & 93.4 & 48.1 & - & - \\
\hline Tribenzoylbalsaminol F (8) & 57.3 & 68.4 & 27.0 & 18.5 & - & - & \\
\hline Balsaminoside A (10) & 4.6 & 4.0 & 99.0 & 44.0 & 26.6 & - & - \\
\hline Balsaminoside B (11) & 2.9 & 6.3 & 98.0 & 95.0 & 35.4 & 33.1 & 22.1 \\
\hline Balsaminoside C (12) & 3.4 & 7.2 & 51.0 & 12.3 & 7.4 & - & - \\
\hline Kuguaglycoside A (13) & 3.9 & 4.7 & - & - & - & - & - \\
\hline Karavilagenin C (17) & 10.4 & 11.2 & 96 & 71.8 & 25.8 & 33.1 & 22.1 \\
\hline Karavoate A (18) & 6.7 & 3.5 & 97 & 92.5 & 28.2 & - & - \\
\hline Karavoate B (19) & 0.5 & 0.5 & 99.0 & 96.1 & 59 & 58.1 & 41.8 \\
\hline Karavoate C (20) & 5.1 & 22.0 & 98.0 & 59.9 & 11.5 & - & - \\
\hline Karavoate D (21) & 1.5 & 0.4 & 93.4 & 82.5 & 34.4 & 45.5 & 12.3 \\
\hline Karavoate M (30) & 1.3 & 0.6 & 97 & 87.4 & 13.6 & - & - \\
\hline Karavoate N (31) & 2.4 & 47.9 & 0 & 0 & 0 & - & - \\
\hline Karavilagenin E (36) & 7.4 & 8.2 & - & - & - & - & - \\
\hline
\end{tabular}

* $\mathrm{mg} \mathrm{kg}^{-1}$ day $^{-1}$

balsaminosides $\mathrm{B}\left(\mathbf{1 1}, \mathrm{IC}_{50}=2.9\right.$ and $6.3 \mu \mathrm{M}$, for 3D7 and $\mathrm{Dd} 2$, respectively $), \mathrm{C}\left(\mathbf{1 2}, \mathrm{IC}_{50}=3.4\right.$ and $7.2 \mu \mathrm{M}$, for 3D7 and Dd2, respectively), and $\mathrm{A}\left(\mathbf{1 0}, \mathrm{IC}_{50}=4.6\right.$ and $4.0 \mu \mathrm{M}$, for 3D7 and Dd2, respectively) (Ramalhete et al. 2010, 2011b). Significant activity was also found for karavilagenins $\mathrm{E}\left(\mathbf{3 6}, \mathrm{IC}_{50}=7.4\right.$ and $8.2 \mu \mathrm{M}$, for 3D7 and $\mathrm{Dd} 2$, respectively), and $\mathrm{C}(\mathbf{1 7}$, $\mathrm{IC}_{50}=10.4$ and $11.2 \mu \mathrm{M}$, for 3D7 and Dd2, respectively), sharing the same side chain and a methoxyl group at C-7 (Ramalhete et al. 2010, 2011a, b). Interestingly, an increase of activity was observed for some acyl derivatives of karavilagenin C (17) (Ramalhete et al. 2011b). In fact, karavoates $\mathrm{B}\left(\mathbf{1 9}, \mathrm{IC}_{50}=0.5\right.$ and $0.5 \mu \mathrm{M}$, for 3D7 and Dd2, respectively) and D (21, $\mathrm{IC}_{50}=1.5$ and $0.4 \mu \mathrm{M}$, for 3D7 and $\mathrm{Dd} 2$, respectively), where both C-3 and C-23 hydroxyl groups were esterified with acetyl or propanoyl moieties, showed to be 20 -fold more active against both strains than the parent compound karavilagenin C (Ramalhete et al. 2011b). On the other hand, a decrease of activity was observed when only C-23 was esterified with an alkanoyl group, as exemplified by the activity observed for karavoate A (18), when compared with that of karavoate B (19) (Ramalhete et al. 2011b). Conversely, from the aroyl set of derivatives of karavilagenin $\mathrm{C}$, the best antimalarial activity was achieved for the monoesters, as exemplified by the activity of monoester karavoate $\mathrm{M}\left(\mathbf{3 0}, \mathrm{IC}_{50}=1.3\right.$ and $0.6 \mu \mathrm{M}$, for 3D7 and Dd2, respectively), when compared to that displayed by the diester karavotate $\mathrm{N}(\mathbf{3 1}$, $\mathrm{IC}_{50}=2.4$ and $47.9 \mu \mathrm{M}$, for 3D7 and Dd2, respectively). These results provided evidence for the importance of molecular steric effects on the antimalarial activity of cucurbitane-type triterpenoids (Ramalhete et al. 2011b). The same steric influence was also observed for balsaminol F (6) and corresponding derivatives (7 and 8), showing triacetylbalsaminol F (7), bearing acetyl group at C-3, C-7, and $\mathrm{C}-23$, the best results on both tested strains $\left(\mathrm{IC}_{50}=0.8\right.$ and $0.4 \mu \mathrm{M}$, for 3D7 and $\mathrm{Dd} 2$, respectively). The tribenzoyl derivative of balsaminol F (6), having one of the highest molecular volumes, showed a weak activity $\left(8, \mathrm{IC}_{50}=57\right.$ and $68 \mu \mathrm{M}$, for $3 \mathrm{D} 7$ and $\mathrm{Dd} 2$, respectively) (Ramalhete et al. 2011a). 
The above results are related with the ability of these compounds to stop parasite growth and development in red blood cell cultures. However, the in vitro antiplasmodial effect can be also studied in the liver stage of the parasite. This assay, using Huh-7 cells infected with a firefly luciferase-expressing $P$. berghei line, PbGFP-Luccon, was performed for a set of twenty-two compounds $(\mathbf{1}, \mathbf{2}, \mathbf{6}-\mathbf{8}, \mathbf{1 1}-\mathbf{1 3}, \mathbf{1 7}-\mathbf{2 3}$, 25-27, 30, 31) (Ramalhete et al. 2011a, 2014). Interestingly, compounds with the best antimalarial results on blood-stages of $P$. falciparum also exhibited a significant in vitro activity against $P$. berghei liver stages (Table 4), as exemplified by karavoate B (19) and triacetylbalsaminol F (7), showing $99 \%$ and $98 \%$ of parasitaemia reduction, respectively, at $15 \mu \mathrm{M}$. Both compounds displayed a significant activity at $1 \mu \mathrm{M}$, the lowest concentration used in these assays, decreasing $P$. berghei hepatic load by $60 \%$ for karavoate B (19), and 48\% for triacethylbalsaminol F (7) (Ramalhete et al. 2011a, 2014). Balsaminol F (6), balsaminoside B (11), and triacetylbalsaminol F (7) showed to act on the parasite's intracellular liver stages, having little or no influence on parasite mobility/invasion (Ramalhete et al. 2011a). The majority of the compounds did not show toxicity on the tested cell lines (Ramalhete et al. 2010, 2011b, 2014). Moreover, the antimalarial activity of some of the most active compounds, as karavoate B (19) and karavoate D (21), was substantiated by testing their in vivo activity against $P$. berghei Vincke and Lips NK65-infected mice, using the four-day suppressive test. Karavoate B (19) exhibited a significant suppression of parasitaemia (58.1\%) in mice infected with $P$. berghei when a dose of $50 \mathrm{mg} \mathrm{kg}^{-1} \mathrm{day}^{-1}$ was administered by sub-cutaneous route (Rocha e Silva et al. 2015). When comparing the average survival times of untreated and treated animals with compounds, similar results were observed, which might be explained by the incomplete suppression of parasitaemia or rapid metabolism/excretion of compounds by the animals (Rocha e Silva et al. 2015). No signs of toxicity were observed, thus corroborating the in vitro results of these compounds against MCF-7 and Huh-7 cells (Ramalhete et al. 2011b, a, 2014; Rocha e Silva et al. 2015).

Compounds 6, 10-12, 17-20, 26, and 30 were also tested for their activity against schistosomiasis. This parasitic disease is caused by trematode adult worms from the Schistosoma genus (namely $S$. mansoni, $S$. haematobium, and $S$. japonicum), chronically affecting liver and gastrointestinal tract (Molehin 2020). In an in vitro assay, using $S$. mansoni adult worms, the compounds were tested at concentrations ranging from 10 to $100 \mu \mathrm{M}$. Karavilagenin C (17) and balsaminol F (6) were the most active, causing $100 \%$ of $S$. mansoni death, at $50 \mu \mathrm{M}$, after $24 \mathrm{~h}$ of exposure. Moreover, at concentrations among 10 and $50 \mu \mathrm{M}$, both compounds caused significant reduction in the motor activity of adult worms and significantly decreased egg production. Additionally, all of the paired adult worms were separated into individual male and female worms after $24 \mathrm{~h}$ of incubation with $50 \mu \mathrm{M}$ of compound 6 and $25 \mu \mathrm{M}$ of compound 17 after $24 \mathrm{~h}$ of exposure (Ramalhete et al. 2012).

\section{Antidiabetic activity}

Diabetes mellitus is an endocrine disorder characterized by chronic hyperglycemia with changes on carbohydrate, fat and protein metabolism due to defects in insulin secretion, insulin action, or both. This leads to chronic complications affecting several key organs, namely, eyes, blood vessels, nerves and kidneys. According to WHO, diabetes is considered an epidemic disease with high rate of morbidity and mortality, being the direct cause of 1.5 million deaths, in 2019 (WHO 2021b). Currently, there are several categories of antidiabetic drugs, which differ in the way they act on blood glucose level reduction, namely insulin analogues, sulphonylureas, biguanides, dipeptidyl peptidase- 4 inhibitors, thiazolidiones, and $\alpha$ glucosidase inhibitors, among others. Despite that, there is an ongoing effort to find out more effective and affordable antidiabetic drugs, with less side effects (American Diabetes Association 2020; Knura et al. 2021). Taking advantage of the ethnopharmacological uses, plants have been selected for bioassay-guided isolation and identification of new lead antidiabetic compounds (Barzkar et al. 2020; Gaonkar and Hullatti 2020; Fu et al. 2021; Wasana et al. 2021; Lee et al. 2021; Ignat et al. 2021; Abu-Odeh and Talib 2021). Thus, metformin, the drug mostly prescribed on the treatment of type- 2 diabetes, is a synthetic derivative of galegine, isolated from Galega officinalis L. (Fabaceae) (Cragg and Newman 2013; Bailey 2017). 
Plants from Momordica genus, particularly $M$. charantia, are known to be used in traditional medicine due to their antidiabetic effect (Grover and Yadav 2004; Tan et al. 2016; Zhang et al. 2016; Salehi et al. 2019). Regarding M. balsamina, in South Africa, Bapedi traditional healers use the extract obtained from its roots, cooked during 5-10 min, to reduce blood sugar. An infusion of this plant is also used with the same function by Zulu population (Thakur et al. 2009; Semenya et al. 2012), while in some South Africa regions a decoction of leaves is orally taken, to stabilize blood sugar levels (Mokganya and Tshisikhawe 2019). Therefore, to validate traditional medicine, the antidiabetic and the blood glucose lowering effect of $M$. balsamina have been studied (Table 5). M. balsamina aqueous and organic extracts were reported to stimulate the glucose utilization in hepatocytes (Chang liver cells) and myocytes (C2C12 muscle cells) in greater extension than the positive controls metformin and insulin, respectively. However, as stated, extracts showed some toxicity at tested concentrations (van de Venter et al. 2008). On the other hand, in vivo studies performed in rabbit models and diabetic rats treated with $250 \mathrm{mg} / \mathrm{kg} /$ day of methanol and chloroform extracts led to a reduction in fasting blood glucose comparable to those of the positive controls glibenclamide $(0.23 \mathrm{mg} / \mathrm{kg} /$ day $)$ and metformin (15 mg/kg/day), respectively (Kaushik et al. 2017; Sani et al. 2019). From the fractionation of the bioactive chloroform fruit extract, three cucurbitane-type compounds (43-45, Fig. 10) were isolated and characterized (Kaushik et al. 2017). The presence of these cucurbitacins was associated with the pharmacological effect of the extract (Kaushik et al. 2017), however further studies are needed to ensure the association. Previously, in other study, using a methanol:water (7:3) extract, a reduction of blood glucose level in alloxan induced Wistar rats, at $1000 \mathrm{mg} / \mathrm{kg}$, comparable to that of chlorpropamide $(400 \mathrm{mg} / \mathrm{kg}$ ), was also observed (Otimenyin et al. 2008).

Although the authors claimed antidiabetic effects of the extracts comparable with the positive controls, the doses needed to achieve this biological effect were much higher than those that displayed antiparasitic activities. For instance, in the studies reported by Sani et al., the concentration was 1000 -fold higher than that of the positive control glibenclamide, making controversial the meaning of the results (Sani et al. 2019).
According to Gertsch (Gertsch 2009), the interest of in vivo pharmacological effects observable with doses of $\geq 200 \mathrm{mg} / \mathrm{kg} /$ day is questionable.

\section{Antibacterial activity}

The impact of bacterial diseases on human health is particularly significant in low-income countries, where poor infection prevention and control strategies and the misuse of antibiotics, when available, contribute for high mortality rates, and the emergence of drug resistance. The development of resistance to antimicrobial agents currently represents one of the most serious threats to global health since multidrugresistant bacteria are found in all regions of the world and spread easily (Sartelli et al. 2020; WHO 2020b). This global public health problem is further exacerbated by the lack of development of new antibacterial compounds (WHO 2019; Plackett 2020). Natural sources, due to their great chemical diversity combined with high bioactivity, are a remarkable source of potential agents against bacterial resistance (WHO 2019; Franco and Vázquez 2020).

M. balsamina has been used in African traditional medicine for the treatment of infection diseases, which has attracted the attention of the scientific community (Madureira et al. 2012). Several studies investigated the antibacterial properties of this plant and the results of some of them are depicted in Table 5 .

The dried aerial parts of $M$. balsamina were extracted sequentially with hexane, dichloromethane, ethyl acetate and methanol and the antimicrobial activity of the obtained extracts was screened, by our group, against several Gram-positive and Gram-negative bacteria (Madureira et al. 2012). No relevant activity was observed when $n$-hexane and dichloromethane extracts were tested towards Staphylococcus aureus, Enterococcus faecalis, Klebsiella pneumoniae, Pseudomonas aeruginosa and Mycobacterium smegmatis (MIC values $>125 \mu \mathrm{M}$ ). However, the methanol extract exhibited relevant activity against Mycobacterium smegmatis with a MIC value of $31.0 \mu \mathrm{g} / \mathrm{mL}$ (control rifampicin, MIC $\leq 3.5 \mu \mathrm{g}$ / $\mathrm{mL}$ ), according to the criteria established in literature (Cos et al. 2006). More interestingly, the ethyl acetate extract inhibited the development of Enterococcus faecalis with a MIC of $7.5 \mu \mathrm{g} / \mathrm{mL}$ (Table 5) (positive controls vancomycin, $\mathrm{MIC}=1.5 \mu \mathrm{g} / \mathrm{mL} \quad$ and 
Table 5 Biological properties of M. balsamina extracts and isolated compounds

\begin{tabular}{llll}
\hline Compound/ & Type & Cell type/Bacteria/ & Major findings/ Therapeutic action/pathway \\
Composition of the & Animal model & \\
extract & assay & & \\
\hline
\end{tabular}

\section{Antidiabetic activity}

\begin{tabular}{|c|c|c|c|c|c|}
\hline \multicolumn{2}{|c|}{$\begin{array}{l}\text { Aqueous and organic } \\
\text { extracts from stems } \\
\text { and flowers }\end{array}$} & $\begin{array}{l}\text { In } \\
\text { vitro }\end{array}$ & $\begin{array}{l}\text { Chang liver and } \\
\text { Murine } \mathrm{C} 2 \mathrm{C} 12 \\
\text { myoblasts }\end{array}$ & $\begin{array}{l}50 \mu \mathrm{g} / \mathrm{mL} \text { of extract stimulate glucose utilization in } \\
\text { hepatocytes ( } 3 \mathrm{~h} \text { treatment) and myocytes }(1 \mathrm{~h} \\
\text { treatment). However, treatment during } 48 \mathrm{~h} \text { with } \\
12 \mu \mathrm{g} / \mathrm{mL} \text { of extracts exhibited some degree of toxicity }\end{array}$ & $\begin{array}{l}\text { Van de } \\
\text { Venter } \\
\text { et al. } \\
(2008)\end{array}$ \\
\hline \multicolumn{2}{|l|}{$\begin{array}{l}\text { Chloroform fruits } \\
\text { extract }\end{array}$} & $\begin{array}{l}\text { In } \\
\text { vivo }\end{array}$ & $\begin{array}{l}\text { Streptozotocin- } \\
\text { nicotinamide-induced } \\
\text { diabetic animals }\end{array}$ & $\begin{array}{l}250 \mathrm{mg} / \mathrm{kg} / \text { day (during } 1 \text { week) lowers elevated blood } \\
\text { glucose level }\end{array}$ & $\begin{array}{l}\text { Kaushik } \\
\text { et al. } \\
\text { (2017) }\end{array}$ \\
\hline \multicolumn{2}{|c|}{$\begin{array}{l}\text { Methanol extract from } \\
\text { stem, roots, leaves } \\
\text { and seeds }\end{array}$} & $\begin{array}{l}\text { In } \\
\text { vivo }\end{array}$ & $\begin{array}{l}\text { Alloxan induced } \\
\text { diabetic rabbits }\end{array}$ & $\begin{array}{l}\text { Treatment with } 200 \mathrm{mg} / \mathrm{kg} \text { of extract during } 24 \mathrm{~h} \text { induces } \\
\text { a reduction in blood glucose levels }\end{array}$ & $\begin{array}{l}\text { Sani et al. } \\
\text { (2019) }\end{array}$ \\
\hline \multicolumn{6}{|c|}{ Antibacterial Activity } \\
\hline $\begin{array}{l}\text { Ethyl acetate } \\
\text { aerial parts } \\
\text { extract }\end{array}$ & $\begin{array}{l}\text { In } \\
\text { vitro }\end{array}$ & \multicolumn{2}{|c|}{ Enterococcus faecalis } & $\begin{array}{l}\text { Growth inhibition activity } \\
\mathrm{MIC}=7.5 \mu \mathrm{g} / \mathrm{mL} \text { (determined after } 24 \mathrm{~h} \text { of incubation) }\end{array}$ & $\begin{array}{l}\text { Madureira } \\
\text { et al. } \\
\text { (2012) }\end{array}$ \\
\hline $\begin{array}{l}\text { Karavilagenin } \mathrm{C} \\
\text { (17) }\end{array}$ & In & \multicolumn{2}{|c|}{$\begin{array}{l}\text { Methicillin-resistant } \\
\text { Staphylococcus aureus } \\
\text { (MRSA) COL } \mathrm{OXA}\end{array}$} & $\begin{array}{l}\text { Inhibition of the efflux pump system. At } 3 \mu \mathrm{M} \text { increased } \\
\text { the intracellular accumulation of ethidium bromide } \\
\text { ( } 30 \text { min period) }\end{array}$ & $\begin{array}{l}\text { Ramalhete } \\
\text { et al. } \\
\text { (2011c) }\end{array}$ \\
\hline $\begin{array}{l}\text { Balsaminagenin } \\
\text { B (4) }\end{array}$ & $\begin{array}{l}\text { In } \\
\text { vitro }\end{array}$ & \multicolumn{2}{|c|}{$\begin{array}{l}\text { Enterococcus faecalis } \\
\text { ATCC } 29,212\end{array}$} & $\begin{array}{l}\text { Inhibition of the efflux pump system. At } 30 \mu \mathrm{M} \text { increased } \\
\text { the intracellular accumulation of on accumulation of } \\
\text { ethidium bromide ( } 30 \text { min period) }\end{array}$ & $\begin{array}{l}\text { Ramalhete } \\
\text { et al. } \\
\text { (2011c) }\end{array}$ \\
\hline Balsamin & $\begin{array}{l}\text { In } \\
\text { vitro }\end{array}$ & \multicolumn{2}{|c|}{$\begin{array}{l}\text { Staphylococcus epidermidis } \\
\text { Staphylococcus aureus }\end{array}$} & $\begin{array}{l}\text { MIC }(\text { S. epidermidis })=1.56 \mu \mathrm{g} / \mathrm{mL}(24 \mathrm{~h} \text { of incubation }) \\
\operatorname{MIC}(\text { S. aureus })=6.25 \mu \mathrm{g} / \mathrm{mL}(24 \mathrm{~h} \text { of incubation })\end{array}$ & $\begin{array}{l}\text { Ajji et al. } \\
\text { (2016) }\end{array}$ \\
\hline \multicolumn{6}{|l|}{ Antiviral activity } \\
\hline $\begin{aligned} \text { Balsamin In } & \\
& \text { vitro }\end{aligned}$ & \multicolumn{3}{|c|}{$\begin{array}{l}\text { Jurkat } \mathrm{T} \text { cell line and human } \\
\text { primary CD4 + T cells (HIV } \\
\text { assays) } \\
\text { A549 (influenza virus assay) }\end{array}$} & $\begin{array}{l}\text { Balsamin, at } 0.22 \mu \mathrm{M} \text {, inhibits HIV-1 replication, by } \\
\text { interfering with the translation step of the viral proteins } \\
(\mathrm{P} 55, \mathrm{P} 41 \text { and } \mathrm{P} 24) \text { (effects accessed after } 3 \text { days of } \\
\text { treatment) } \\
\text { Al same dose also impedes influenza virus replication }(24 \mathrm{~h} \\
\text { treatment) }\end{array}$ & $\begin{array}{l}\text { Kaur } \\
\text { et al. } \\
(2013)\end{array}$ \\
\hline
\end{tabular}

\section{Antioxidant Activity}

\begin{tabular}{|c|c|c|c|c|}
\hline $\begin{array}{l}\text { Methanol } \\
\text { leaf } \\
\text { extract }\end{array}$ & $\begin{array}{l}\text { In } \\
\text { vitro }\end{array}$ & $\begin{array}{l}\text { 2,2- diphenyl-1-pycril } \\
\text { hydrazyl (DPPH) } \\
\text { photometric assay }\end{array}$ & $\begin{array}{l}\text { At } 100,000 \mu \mathrm{g} / \mathrm{ml} \text { reach } 92-96 \% \text { free radical scavenge } \\
\text { capacity. Rutin at } 610.5 \mu \mathrm{g} / \mathrm{ml} \text { was used as control } \\
(100 \%) \text {. Extract was allowed to react for } 30 \mathrm{~min} \text { at room } \\
\text { temperature }\end{array}$ & $\begin{array}{l}\text { Odhav et al. (2007), } \\
\text { Akula and Odhav } \\
\text { (2008) }\end{array}$ \\
\hline
\end{tabular}

\section{Anti-inflammatory Activity}

\begin{tabular}{|c|c|c|c|c|}
\hline $\begin{array}{l}\text { Aqueous } \\
\text { leaves } \\
\text { extract }\end{array}$ & $\begin{array}{l}\text { In } \\
\text { vivo }\end{array}$ & $\begin{array}{l}\text { Egg albumin- } \\
\text { induced oedema } \\
\text { rat }\end{array}$ & $\begin{array}{l}\text { At } 400 \mathrm{mg} / \mathrm{kg} \text { significantly reduced the edema induced by egg albumin } \\
\text { with higher extent than the standard anti-inflammatory compound } \\
\text { aspirin (at } 30 \mathrm{mg} / \mathrm{kg} \text { ) }\end{array}$ & $\begin{array}{l}\text { Karumi et al. } \\
\text { (2003) }\end{array}$ \\
\hline $\begin{array}{l}\text { Methanol } \\
\text { leaves } \\
\text { extract }\end{array}$ & $\begin{array}{l}\text { In } \\
\text { vitro }\end{array}$ & $\begin{array}{l}\text { Soybean } \\
\text { lipoxygenase }\end{array}$ & $\begin{array}{l}\text { Potent inhibition of the 5-lipoxygenase (5-Lox) activity with an } \mathrm{IC}_{50} \text { of } \\
40.3 \mu \mathrm{g} / \mathrm{mL}\end{array}$ & $\begin{array}{l}\text { Akula and } \\
\text { Odhav } \\
\text { (2008) }\end{array}$ \\
\hline $\begin{array}{l}\text { Aqueous } \\
\text { leaves } \\
\text { extract }\end{array}$ & $\begin{array}{l}\text { In } \\
\text { vitro }\end{array}$ & $\begin{array}{l}\text { COX-1, COX-2 } \\
\text { enzymatic } \\
\text { assays }\end{array}$ & $\begin{array}{l}\text { At a concentration of } 2000 \mu \mathrm{g} / \mathrm{mL} \text { exhibited anti-inflammatory } \\
\text { activity through inhibition of COX-1 and COX-2 }\end{array}$ & $\begin{array}{l}\text { Ndhlala et al. } \\
\text { (2011) }\end{array}$ \\
\hline
\end{tabular}


Table 5 continued

\begin{tabular}{|c|c|c|c|c|}
\hline \multicolumn{5}{|c|}{ Antibacterial Activity } \\
\hline $\begin{array}{l}\text { Ethanol } \\
\text { leaves } \\
\text { extract }\end{array}$ & $\begin{array}{l}\text { In } \\
\text { vivo }\end{array}$ & $\begin{array}{l}\text { Carbon tetrachloride } \\
\text { liver injury induced } \\
\text { in Wistar albino rats }\end{array}$ & $\begin{array}{l}250 \mathrm{mg} / \mathrm{kg} / \text { day induce a decrease in serum levels of SGOT }(23.8 \%) \text {, } \\
\text { SGPT }(28.5 \%) \text {, ALP }(17.8 \%) \text { and bilirubin }(38.2 \%) \text {. Silymarin } \\
(10 \mathrm{mg} / \mathrm{kg} / \mathrm{day}) \text { was used as positive control and induced a reduction } \\
\text { of } 65.1 \% \text { (SGOT), } 72.2 \% \text { (SGPT), } 41.1 \% \text { (ALP), and } 62.2 \% \\
\text { (bilirubin) respectively }\end{array}$ & $\begin{array}{l}\text { Alqasoumi } \\
\text { et al. } \\
(2009)\end{array}$ \\
\hline \multicolumn{5}{|c|}{ Antinociceptive (analgesic) activity } \\
\hline $\begin{array}{l}\text { Aqueous } \\
\text { leaves } \\
\text { extract }\end{array}$ & $\begin{array}{l}\text { In } \\
\text { vivo }\end{array}$ & $\begin{array}{l}\text { Acetic acid-induced } \\
\text { writhes and stretches in } \\
\text { rats }\end{array}$ & $\begin{array}{l}\text { Induced pain threshold increases in a dose dependent manner. } \\
\text { Protective effect of } 200 \mathrm{mg} / \mathrm{kg} \text { of extract ( } 55 \% \text { protection) was } \\
\text { found to be higher than that of } 30 \mathrm{mg} / \mathrm{kg} \text { pentazocine }(48.8 \% \\
\text { protection) }\end{array}$ & $\begin{array}{l}\text { Karumi } \\
\text { et al. } \\
(2003)\end{array}$ \\
\hline \multicolumn{5}{|c|}{ Anti-ulcer activity } \\
\hline $\begin{array}{l}\text { Aqueous } \\
\text { leaves } \\
\text { extract }\end{array}$ & $\begin{array}{l}\text { In } \\
\text { vivo }\end{array}$ & $\begin{array}{l}\text { Ethanol-induced gastric } \\
\text { ulcer in Wistar rats }\end{array}$ & \multicolumn{2}{|c|}{$\begin{array}{l}\text { At } 800 \mathrm{mg} / \mathrm{kg} \text { revealed an effect on treatment and prevention of ulceration } \\
\text { comparable to that of ranitidine }(100 \mathrm{mg} / \mathrm{kg}) \text {. Pre-treatment with extract/ } \\
\text { ranitidine } 1 \mathrm{~h} \text { before ethanol-induced ulcer. Results accessed } 1 \mathrm{~h} \text { after the } \\
\text { administration of ethano }\end{array}$} \\
\hline \multicolumn{5}{|c|}{ Antidiarrheal activity } \\
\hline $\begin{array}{l}\text { Methanol } \\
\text { fruit } \\
\text { extract }\end{array}$ & $\begin{array}{l}\text { In } \\
\text { vivo }\end{array}$ & $\begin{array}{l}\text { Castor oil induced } \\
\text { diarrhea in Swiss albino } \\
\text { mice. }\end{array}$ & $\begin{array}{l}\text { At } 800 \mathrm{mg} / \mathrm{kg} \text { avoid castor oil induced diarrhea by inhibiting } \\
\text { intestinal secretion and transit time. Loperamide }(5 \mathrm{mg} / \mathrm{kg}) \text { and } \\
\text { atropine at } 3 \mathrm{mg} / \mathrm{kg} \text { ) were used as reference drugs with similar or } \\
\text { better results }\end{array}$ & $\begin{array}{l}\text { Okpara } \\
\text { et al. } \\
(2017)\end{array}$ \\
\hline
\end{tabular}

gentamicin, $\mathrm{MIC}=1.5 \mu \mathrm{g} / \mathrm{mL})$. This ethyl acetate extract was found to be rich in cucurbitane-type triterpenoids, which suggests that these compounds may play an important role in the antibacterial activity (Madureira et al. 2012). Thus, this extract clearly warrants further studies to explore their anti-microbial potential against this bacterial strain (Madureira et al. 2012).

We also evaluated the ability of six cucurbitanetype triterpenoids $(\mathbf{1}, \mathbf{6}, \mathbf{1 0}, \mathbf{1 4}, \mathbf{1 5}$, and $\mathbf{1 7}$, obtained from the aerial parts of $M$. balsamina, to modulate the bacterial efflux pump systems in Gram-positive (meticillin-resistant Staphylococcus aureus (MRSA) COL $_{\text {OXA }}$ and Enterococcus faecalis ATCC 29,212) and Gram-negative (Salmonella typhimurium 5408, Salmonella typhimurium 5408CIP, Escherichia coli AG100 wild-type strain and E. coli AG100TET8) bacterial strains (Ramalhete et al. 2011c). The evaluation of the efflux activity was performed using a semi-automated method that measures accumulation of the universal efflux pump substrate ethidium bromide (EtBr) after treatment with the tested com- pounds at $3 \mu \mathrm{M}$ and $30 \mu \mathrm{M}$. All compounds inhibited the efflux pump systems of the Gram-positive bacteria

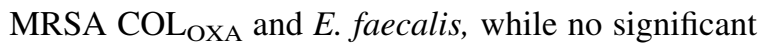
activity against the efflux systems of Gram-negative $S$. typhimurium and E. coli strains was observed. The most active compounds on the accumulation of EtBr in MRSA COL ${ }_{\text {OXA }}$, at $3 \mu \mathrm{M}$, were karavilagenin $\mathrm{C}$ (17) and balsaminol $\mathrm{F}(\mathbf{6})$. For this bacterial strain, a correlation between activity and the topological polar surface area of the compounds was found. For $E$. faecalis ATCC 29,212, balsaminagenin B (15) was the most active compound at $30 \mu \mathrm{M}$, while karavilagenin C (17) weakly inhibited the efflux of EtBr. It is also important to note that none of these derivatives exhibited toxicity at the concentrations tested as determined by the trypan blue exclusion assay. This study highlighted cucurbitane-type triterpenoids as possible lead compounds in the development of efflux pump inhibitors of Gram-positive bacteria (Ramalhete et al. 2011c).

More recently, in 2018, Souda and co-workers claimed that the methanol extract of the aerial parts of 
M. balsamina exhibited anti-microbial activity against Streptococcus agalactiae (MIC $=234 \mu \mathrm{g} / \mathrm{mL}$ ) and Gram negative Proteus mirabilis (MIC $=234 \mu \mathrm{g}$ / $\mathrm{mL}$ ) (Souda et al. 2018). However, considering the criteria for activity (relevant and selective activity relates to MIC values below $100 \mu \mathrm{g} / \mathrm{mL}$ for extracts), as established by Cos et. al. (Cos et al. 2006), it is important to mention that the MIC exhibited by this extract is too high to be considered active.

Balsamin is a ribosome inactivating protein (RIP) isolated from the seeds of M. balsamina that has been reported do display a broad-spectrum antibacterial activity. It was found to inhibit the growth of Staphylococcus aureus, Salmonella enterica, Staphylococcus epidermidis and Escherichia coli, in a dose dependent way, with MIC values, determined by the broth microdilution method (using ampicillin $50 \mu \mathrm{g}$ / $\mathrm{mL}$ as positive control), ranging from 1.56 to $12.50 \mu \mathrm{g} / \mathrm{mL}$ (Table 5). On the other hand, Pseudomonas aeruginosa (MIC $=25 \mu \mathrm{g} / \mathrm{mL}$ ) and Enterococcus faecalis ( $\mathrm{MIC}=50 \mu \mathrm{g} / \mathrm{mL}$ ) were found to be less susceptible to this protein (Ajji et al. 2016). Considering the results obtained, and due to the limited amount of balsamin in the seeds, later, the same research group, developed a study aiming at finding a solution for this limitation. For that, Parminder Ajji and co-workers developed heterologous expression of His-tagged $r$ Balsamin in an Escherichia coli expression system (Ajji et al. 2018). Antimicrobial assays showed that the recombinant balsamin maintained similar minimum inhibitory concentration values for the various pathogens ranging between 1.56 and $25 \mu \mathrm{g} / \mathrm{mL}$ (Ajji et al. 2018). However, the MIC values for the standard antibiotic ampicillin used as positive control were not determined, which would be important to properly interpret the antibacterial activity of this protein, by comparison with the one displayed by the control (Cos et al. 2006)(Eloff 2019).

\section{Antiviral activity}

Despite the tremendous progress made in last decades, viral diseases, such as acquired immunodeficiency syndrome, respiratory diseases, viral hepatitis, are still among the leading causes of death worldwide. A very recent example of the tremendous impact of viral diseases in human health is the novel SARS-CoV-2 virus that emerged in December 2019 and rapidly caused a global outbreak being responsible for more than 3.93 million deaths worldwide until mid-2021, since the pandemic is still ongoing (Macedo et al. 2021; Vilar and Isom 2021; WHO 2021c). Many of these viruses are lacking effective vaccines or therapies. In addition, the development of antiviral drug resistance is an increasing concern in immunocompromised patient populations, and some of antiviral drugs available induce serious adverse effects. This emphasizes the need of discovering novel antiviral drugs for the situations where vaccines and standard therapies are lacking. Several medicinal plants, and isolated natural products have been investigated for their antiviral properties and many presented a promising potential for the management and control of viral infections acting by complementary and overlapping mechanism of action (Kitazato et al. 2007).

It has been reported that $M$. balsamina possess antiviral properties namely against the human immunodeficiency virus 1 (HIV-1) (Bot et al. 2007)(Gbodossou 2010). Kaur et al. (2013) investigated the effect of purified balsamin towards HIV-1 in Jurkat T cells and Primary CD4 + T lines (Table 5). They found that this protein decreased the HIV replication in Jurkat $\mathrm{T}$ cells (reaching 99\% inhibition at $3.57 \mu \mathrm{M}$ in growth curve assays), with $\mathrm{IC}_{50}$ values in the nanomolar range $(0.0102 \mu \mathrm{M})$, and almost completely abolished accumulation of HIV-1 capsid protein (p24) in cytoplasm. Azidothymidine (AZT) was included as positive control for the HIV-1 inhibition. To exclude that balsamin antiviral effect is a consequence of a putative effect on cell health, the trypan blue exclusion counting method was used to evaluate the effect of balsamin on the viability of Jurkat cells. Despite the $\mathrm{TC}_{50}$ (dose that produces toxic effects in 50 percent of a population) value of balsamin $(6.25 \mu \mathrm{M})$ against Jurkat revealed to be much than that of AZT $(329 \mu \mathrm{M})$, no significant toxicity was observed at the doses at which balsamin showed considerable antiviral activity. Similar effects were also observed in primary $\mathrm{CD} 4+\mathrm{T}$ cells, without affecting cell viability $\left(\mathrm{TC}_{50}\right.$ balsamin $=8.75 \mu \mathrm{M}$ by comparison with $\mathrm{TC}_{50}$ of $\mathrm{AZT}=31 \mu \mathrm{M})$. Studies performed to explore the mechanism of action of balsamin, suggested that the antiviral effect was related with the translation step of viral replication, between the reverse transcription and the production of new viral particles. Accordingly, 
balsamin inhibited the translation step of the viral proteins p24, p41 and p55 that occurs prior to HIV-1 bidding and release and independent of the cytotoxic effects. Importantly, this study also demonstrated that balsamin hampered influenza virus replication. This result suggests that this protein could possess antiviral activity against a broad range of viruses (Kaur et al. 2013). Despite the reported antiviral properties of $M$. balsamina, additional studies are needed to further support this biological activity.

\section{Other reported activities}

\section{Antioxidant activity}

Oxidative stress is a consequence of the imbalance between oxidant and antioxidant, in favor of the formers, giving an overproduction of reactive oxygen species (ROS). ROS have deleterious effects in several diseases, such as cancer, cardiovascular disease, brain dysfunction, and accelerate ageing. Thus, the regulation of the redox state is critical for cell viability, activation, proliferation, and organ function. Fortunately, the physiological antioxidant systems control are usually effective in blocking the harmful effects of ROS, however in pathological conditions, these systems could not be sufficient to counterbalance the effect of these harmful substances (Birben et al. 2012). In these situations, the use of compounds able to prevent or reduce the magnitude of these oxidative mediators (antioxidants) is of utmost importance to protect cells, tissues and organs.

Although synthetic antioxidants have been extensively used over the years, safety issues have been raised over time, such as the possible association of the long-term intake of these antioxidants with health issues, including skin allergies, gastrointestinal tract problems, and in some cases increasing the risk of cancer. Antioxidants from natural sources still represent a good alternative for synthetic ones, despite the need of more studies to completely assess their safety (Faujdar et al. 2013).

The methanol extract from leaves of M. balsamina, at $10^{5} \mu \mathrm{g} / \mathrm{ml}$, was found to have free radical scavenger activity, almost completely inhibiting 2,2-diphenyl-2picrylhydrazyl radical (DPPH) absorption (around $94 \%$ ). Rutin, at $610.5 \mu \mathrm{g} / \mathrm{ml}$, was used as positive control to $100 \%$ scavenging capacity (Table 5) (Odhav et al. 2007; Akula and Odhav 2008). On the other hand, the aqueous extract was a considerably less effective radical scavenger (42.5\%). A correlation between the phenolic content of the methanol extract and its high radical scavenging activity was suggested by the authors (Akula and Odhav 2008). It should be noted that high concentrations of extract are needed to produce the maximum antioxidant activity, which could rise some concerns regarding its safety. Moreover, despite the established association between the phenolic content and the antioxidant activity, it is important to determine which phenolic compounds are present within the extract to confirm this association.

\section{Anti-inflammatory activity}

Inflammation is part of the process by which body respond to aggression by virus, bacteria or fungi, cancer, ischemia, allergen, toxic compounds, and tissue lesion. Without this process, these injuries could become deadly. However, if inflammation process occurs for too long it could become problematic (Das 2011). Natural products with anti-inflammatory activity, such as the salicylate-containing plants, have long been used as a folk remedy for inflammatory conditions. The anti-inflammatory drug aspirin, extensively used in current clinical practice, is derived from these natural sources. Thus, natural products represent a hopeful starting point for the development of novel anti-inflammatory compounds (Yuan et al. 2006; Attiq et al. 2018).

The anti-inflammatory properties of the aqueous leaves extract of M. balsamina was firstly evaluated in egg albumin-induced oedema rat models (Karumi et al. 2003). A dose-dependent reduction in the mean diameter of the paw was observed five hours after treatment with $100-400 \mathrm{mg} / \mathrm{kg}$ of extract, when compared with negative control or aspirin (positive control, $30 \mathrm{mg} / \mathrm{kg}$ ) treated groups. These results gave an indication of the anti-inflammatory effect of the extract (Table 5) (Karumi et al. 2003). However, the toxicity of the extract should be accessed in an appropriate in vivo model to get some insights regarding its safety. Later studies revealed that the methanol extract of $M$. balsamina leaves significantly inhibited the 5-lipoxygenase (5-Lox) activity with an $\mathrm{IC}_{50}$ of $40.3 \mu \mathrm{g} / \mathrm{mL}$ (Table 5). According to the authors, the reported anti-inflammatory activity could 
be explained by the potent free radical scavenging activity of the phenolic compounds present in the extract, which block the arachidonic acid metabolism through the lipoxygenase pathway (Akula and Odhav 2008).

As a part of a study to determine the pharmacological properties of Imbiza ephuzwato, a traditional herbal tonic made from a mixture of 21 medicinal plants used in traditional medicine as a multipurpose remedy, the water extracts of $M$. balsamina leaves showed anti-inflammatory properties by acting in both COX-1 and COX-2 enzymes (Ndhlala et al. 2011). The inhibitory activity of the water extract $(2000 \mu \mathrm{g} /$ $\mathrm{mL}$ ) was found to be higher in the COX-2 bioassay (more than $70 \%$ inhibition) when compared to the COX-1 bioassay, suggesting that these extracts could be selective towards the COX-2 enzyme, and thus avoid the gastric irritation and consequently the risk of gastric ulceration associated with the inhibition of COX-1 (Table 5) (Ndhlala et al. 2011). Despite no mutagenicity was observed in Ames test, new studies using a less concentrated water extract are necessary to confirm the anti-inflammatory potential of the extract.

\section{Hepatoprotective activity}

Due to its role on the regulation of several vital functions such as metabolism, secretion, storage, and detoxification of endogenous and exogenous substances, liver is one of the most important organs of human body. Thus, liver diseases represent a public health problem that imposes a significant socioeconomic burden on patients and the healthcare system. Medicinal plants have been used as a source of new molecules, such as silymarin, schisandrin B, hypophyllanthin, picroside I and kutkoside, for the treatment and prevention of hepatic diseases (Madrigal-Santillán et al. 2014). Toxins, such as carbon tetrachloride, are used to induce liver injuries in animal models. Treatment of Wistar albino rats with carbon tetrachloride induced a significant increase of transaminases (serum glutamate oxaloacetate transaminase (SGOT) and serum glutamate pyruvate transaminase (SGPT)) and alkaline phosphatase (ALP) levels which are markers of hepatic function and decrease the hepatocyte viability. Pre-treatment of the animals with $250 \mathrm{mg} / \mathrm{kg}$ of $M$. balsamina leaves ethanol extract before carbon tetrachloride, led to preservation of cell viability, and decreased the levels of SGOT (23.8\%), SGPT (28.5\%), ALP (17.8\%) and bilirubin (38.2\%) (Table 5). Silymarin (10 mg/kg) was used as reference drug and induced a reduction of $65.1 \%, 72.2 \%, 41.1 \%$, and $62.2 \%$, respectively. In addition, the histological analysis revealed that hepatocytes pre-treated with the extract presented a significant disappearance of necrosis and fatty deposition in the liver and almost clear portal tracts when compared to the cells treated only with carbon tetrachloride. The authors claimed that extracts of $M$. balsamima granted protection against the alterations of several biochemical markers of liver damage (Alqasoumi et al. 2009). However, and considering the dose of extract used, it would be important to assess which compounds are responsible for such activity, to better compare with a reference drug, strongly supporting, or not, the claimed hepatoprotective effects.

\section{Antinociceptive (analgesic) activity}

The sense of pain is a defense mechanism, alerting for danger situations that could cause harm to our body. This sensation makes body stop the action that is causing harm. However, strong pains can cause loss of quality of life and suffering, with serious mental and social implications. In these situations, the pain should be managed by using potent antinociceptive drugs. Some of the most frequently used antinociceptive drugs include paracetamol, and non-steroidal antiinflammatory drugs or even morphine and its derivatives. These drugs, despite being efficient, are sometimes associated with relevant secondary effects, which lead to a continuous effort for new and affordable antinociceptive agents with good efficacy and reduced side effects.

M. balsamina was claimed to possess pain relief properties (Table 5) towards acetic acid-induced writhes and stretches in rats (Karumi et al. 2003). Rats were injected intraperitoneally with aqueous leaves extract at 100, 200 and $400 \mathrm{mg} / \mathrm{kg}, 30 \mathrm{~min}$ before the treatment with acetic acid. An increase in the pain threshold in a dose dependent manner was observed in rats treated with 100 (37.7\% protection), $200(55 \%$ protection) and $400 \mathrm{mg} / \mathrm{kg}$ (71.3\% protection) of plant extract, when compared with control group (treated with distilled water). The protective 
effect obtained for $200 \mathrm{mg} / \mathrm{kg}$ of extract was found to be higher than the effect obtained with $30 \mathrm{mg} / \mathrm{kg}$ of the synthetic opioid pain killer pentazocine (48.8\% protection) (Karumi et al. 2003). Despite these results, further work is needed to identify the compounds responsible for the antinociceptive activity, as well as to study the mechanism of action behind this pharmacological effect.

\section{Anti-ulcer activity}

Gastric ulcer is a common gastrointestinal disorder associated with alcohol consumption, smoking, Helicobacter pylori infection, stress, and unspecific nonsteroidal anti-inflammatory drugs. This disorder presents high incidence rates and could result in death due to complications. Plants could represent a cost-effective and readily accessible alternative for the treatment of this disorder, mainly in low-income countries. Pretreatment with $800 \mathrm{mg} / \mathrm{kg}$ aqueous $M$. balsamina leaf extract significantly reduced the degree of ulceration (around 70\%) in ethanol-induced gastric ulcer Wistar rats. These results were similar to the effect obtained with $100 \mathrm{mg} / \mathrm{kg}$ of ranitidine (a histamine-2 blocker that decreases the stomach acid production) (Table 5) (Mshelia et al. 2017). The authors suggest that the antibacterial and antimicrobial effects of M. balsamina could contribute for its effect on the prevention/ treatment and control of gastric of ulcers. The results are in good agreement with the use of this plant in traditional medicine for stomach disorders, however additional studies need to be performed so this use could be properly supported by scientific data.

\section{Antidiarrheal activity}

If not treated, diarrhea could lead to death, being the cause of several million of human deaths in the world annually (Kent and Banks 2010). M. balsamina is traditionally used in underdeveloped countries, such as Nigeria, to treat an array of diseases, including diarrhea and dysentery. The methanol fruit extract orally administered at $800 \mathrm{mg} / \mathrm{kg}$ to Swiss albino mice avoid the diarrhea induced by castor oil, substantiating its antidiarrheal effect (Table 5), similar to that obtained with the antidiarrheal agent loperamide at $5 \mathrm{mg} / \mathrm{kg}$. On the other hand, the reference drug atropine, at $3 \mathrm{mg} / \mathrm{kg}$, exhibited a stronger effect than the extract $(800 \mathrm{mg} / \mathrm{kg})$ in decreasing the intestinal fluid contents (Okpara et al. 2017). Thus, only by this study and taking into account the high concentration used by the authors, it is not clear that the antidiarrheal effect is one of the relevant pharmacological activities of this plant.

\section{Conclusions and future perspectives}

Momordica balsamina (Cucurbitaceae) is an important vegetable with high nutritional value, and traditionally used to treat several diseases in African countries, such as malaria fevers and diabetes. The main constituents isolated from this species are cucurbitane-type triterpenoids, with different oxidation patterns. Besides cucurbitane-type triterpenes, other terpenoids were also isolated, such as diterpenes. Moreover, flavonoids were also identified in an aqueous-methanol extract of this species.

This review summarized the structures and biological properties of the main constituents extracted from M. balsamina with special focus on our contribution to the phytochemical study of this plant. Several cucurbitacins, most of them new compounds, were isolated from the methanol extract of this species. Several acyl derivatives were also prepared from major compounds. Remarkably, a new carbon skeleton, named cucurbalsaminane, bearing a unique 5/6/3/6/5-fused pentacyclic scaffold and represented by cucurbalsaminones A-C (40-42), was recently characterized by our group. Several of these compounds were found of be strong P-glycoprotein inhibitors in resistant cancer cells, interacted synergistically with the anticancer drug doxorubicin, and were able to kill selectively resistant cancer cells. Moreover, they were found to be efflux pump inhibitors in resistant bacteria. Thus, taking into account their promising ability for reversing multidrug resistance, it would be important to generate new sets of derivatives, thus allowing structure-activity relationship studies for optimizing their structures. In vivo and pharmacokinetics studies should also be performed as well as the evaluation of their potential toxicity. Considering that the development of broad-spectrum inhibitors should be addressed to successfully overcome MDR and better understanding the function and role of ABC-transporters in MDR (Stefan 2019), it is also worthwhile to 
evaluate the ability of these triterpenoids as MRP1 and BCRP inhibitors. In fact, the development of ABC transporter inhibitors, as an approach for overcoming MDR, has been mainly focused on the development of selective P-gp inhibitors. However, the efflux pumps MRP1 and BCRP, which are also strongly implicated in MDR, may be co-expressed with P-gp (Robey et al. 2018), and consequently selectively inhibiting one of these three transporters may originate the upregulation of another.

Interestingly, some of these natural cucurbitanes and derivatives revealed in vitro antimalarial activity, against blood and liver-stages of Plasmodium strains, substantiated by in vivo studies, thus supporting the use of the plant in traditional medicine for treating malaria. However, toxicological, and pharmacokinetics studies need to be performed in order to ensure the safety and effectiveness of the use of M. balsamina extracts in traditional medicine. Regarding the use of single compounds, the design of new derivatives together with new safety tests and the study of the mechanism of action would be of utmost importance. Some of the cucurbitacins showed also schistosomicidal activity. Taking into account the similar mechanism of heme detoxification on both parasites (Stiebler et al. 2011), this can be a key target on the antiparasitic mechanism of action of cucurbitane-type compounds that can be explored in further studies. In fact, Soares et al. proved that the known antimalarial quinoline methanols, namely the alkaloids quinine and quinidine, which interfered with hemozoin formation, have a similar action on Schistossoma parasites (Soares et al. 2009).

In addition, it was also found that extracts and pure compounds (namely curcubitanes) obtained from $M$. balsamina displayed significant antibacterial properties, which renders the interest of this plant in the quest for new antimicrobial agents. Concerning the antidiabetic activity, taking into account the recognized antidiabetic effect of $M$. charantia (Raman and Lau 1996; Chaturvedi 2012), and the results obtained in the reviewed studies, although the use of high concentrations, the antidiabetic properties of M. balsamina are worthy of further studies.

Several other studies regarding the evaluation of the biological activity of diverse M. balsamina extracts of different polarity, report various activities, including anti-inflammatory, antioxidant, and anti-ulcer properties. However, there are some concerns that should be taking in consideration to access which extracts, and activities are worthy of further investigation to confirm the claimed pharmacological effect and find new drug hits. One of the main limitations found in the evaluation of extracts with claimed activity was the high concentration needed to produce the biological effect. When compared with synthetic compounds, natural products, bearing high chemical diversity and very complex structures, namely in terms of chirality, are characterized for having high binding ability to a large number of proteins and other biological targets, thus having an increased probability of generating a biological effect at high concentrations. One other issue, is the composition of the extracts evaluated that was barely explored in the great majority of the studies analyzed. Knowing the composition is of extreme importance not only to investigate which compounds or synergistic interactions are responsible for the biological properties, but also to ensure the standardization of active extracts. Without standardization it is not possible to guarantee that different batches of determined extract will have always the same pharmacological effect. Finally, we also identified some flaws regarding the evaluation of the safety of the extracts, and we consider that an extensive assessment of the toxicological properties of the M. balsamina extracts is mandatory.

Acknowledgements The authors thank Fundação para a Ciência e a Tecnologia (FCT), Portugal, for financial support (project: PTDC/MED-QUI/30591/2017).

Funding PTDC/MED-QUI/30591/2017.

Code availability Not applicable.

\section{Declarations}

Conflict of interest The authors have no conflicts of interest to declare.

\section{References}

Abu-Odeh AM, Talib WH (2021) Middle east medicinal plants in the treatment of diabetes: a review. Molecules 26:742. https://doi.org/10.3390/molecules26030742

Achan J, Talisuna AO, Erhart A et al (2011) Quinine, an old anti-malarial drug in a modern world: role in the treatment of malaria. Malar J 10:144. https://doi.org/10.1186/14752875-10-144 
Ajji PK, Walder K, Puri M (2016) Functional analysis of a type-I ribosome inactivating protein Balsamin from Momordica balsamina with Anti-Microbial and DNase Activity. Plant Foods Hum Nutr 71:265-271. https://doi.org/10.1007/ s11130-016-0555-4

Ajji PK, Sonkar SP, Walder K, Puri M (2018) Purification and functional characterization of recombinant balsamin, a ribosome-inactivating protein from Momordica balsamina. Int J Biol Macromol 114:226-234. https://doi.org/10.1016/ j.ijbiomac.2018.02.114

Akinyemi KO, Mendie UE, Smith ST et al (2005) Screening of some medicinal plants used in south-west Nigerian traditional medicine for anti-salmonella typhi activity. J Herb Pharmacother 5:45-60. https://doi.org/10.1300/ J157v05n01_06

Akula US, Odhav B (2008) In vitro 5-Lipoxygenase inhibition of polyphenolic antioxidants from undomesticated plants of South Africa. J Med Plants Res 2:207-212

Alexander GC, Turner LW, Nartey D et al (1997) Ambulatory treatment of type 2 diabetes in the. Diabetes Care 37:985-992. https://doi.org/10.2337/dc13-2097

Alqasoumi SI, Al-dosari MS, AlSheikh AM, Abdel-kader MS (2009) Evaluation of the hepatoprotective eEffect of Fumaria parviflora and Momordica Balsamina from Saudi Folk medicine against experimentally induced liver injury in rats. Res J Med Plant 3:9-15

American Diabetes Association (2020) Pharmacologic approaches to glycemic treatment: standards of medical care in diabetes-2020. Diabetes Care 43:S98-S110

Ateba SB, Mvondo MA, Ngeu ST et al (2018) Natural terpenoids against female breast cancer: a 5-year recent research. Curr Med Chem 25:3162-3213. https://doi.org/ 10.2174/0929867325666180214110932

Attiq A, Jalil J, Husain K, Ahmad W (2018) Raging the war against inflammation with natural products. Front Pharmacol 9:1-27. https://doi.org/10.3389/fphar.2018.00976

Bailey CJ (2017) Metformin: historical overview. Diabetologia 60:1566-1576

Bandeira SO, Gaspar F, Pagula FP (2001) African ethnobotany and healthcare: emphasis on mozambique. Pharm Biol 39:70-73. https://doi.org/10.1076/phbi.39.s1.70.0002

Barzkar F, Baradaran HR, Khamseh ME et al (2020) Medicinal plants in the adjunctive treatment of patients with type-1 diabetes: a systematic review of randomized clinical trials. J Diabetes Metab Disord 19:1917-1929

Benoit-Vical F, Grellier P, Abdoulaye A et al (2006) In vitro and in vivo antiplasmodial activity of Momordica balsamina alone or in a traditional mixture. Chemotherapy 52:288-292. https://doi.org/10.1159/000095960

Bharathi LK, John KJ (2013) Momordica genus in Asia-an overview. Springer India, New Delhi

Birben E, Sahiner UM, Sackesen C et al (2012) Oxidative stress and antioxidant defense. World Allergy Organ J 5:9-19. https://doi.org/10.1097/WOX.0b013e3182439613

Bot Y, Mgbojikwe LO, Nwosu C et al (2007) Screening of the fruit pulp extract of Momordica balsamina for anti HIV property. African J Biotechnol 6:047-052. https://doi.org/ 10.5897/AJB07.396

Callaghan R, Luk F, Bebawy M (2014) Inhibition of the multidrug resistance P-glycoprotein: time for a change of strategy? Drug Metab Dispos 42:623-631. https://doi.org/ 10.1124/dmd.113.056176

Chang C, Chen C, Liao Y et al (2008) Cucurbitane-Type Triterpenoids from the Stems of Momordica charantia. J Nat Prod 71:1327-1330. https://doi.org/10.1021/ np070532u

Chen J, Chiu M, Nie R et al (2005) Cucurbitacins and cucurbitane glycosides: Structures and biological activities. Nat Prod Rep 22:386-399. https://doi.org/10.1039/b418841c

Chen JC, Lu L, Zhang XM et al (2008) Eight new cucurbitane glycosides, kuguaglycosides A-H, from the root of Momordica charantia L. Helv Chim Acta 91:920-929. https://doi.org/10.1002/hlca.200890097

Chomicki G, Schaefer H, Renner SS (2020) Origin and domestication of Cucurbitaceae crops: insights from phylogenies, genomics and archaeology. New Phytol 226:1240-1255. https://doi.org/10.1111/nph.16015

Chou TC (2006) Theoretical basis, experimental design, and computerized simulation of synergism and antagonism in drug combination studies. Pharmacol Rev 58:621-681. https://doi.org/10.1124/pr.58.3.10

Chou TC (2010) Drug combination studies and their synergy quantification using the chou-talalay method. Cancer Res 70:440-446. https://doi.org/10.1158/0008-5472.CAN-091947

Clarkson C, Maharaj VJ, Crouch NR et al (2004) In vitro antiplasmodial activity of medicinal plants native to or naturalised in South Africa. $J$ Ethnopharmacol 92:177-191. https://doi.org/10.1016/j.jep.2004.02.011

Coban C (2020) The host targeting effect of chloroquine in malaria. Curr Opin Immunol 66:98-107. https://doi.org/10. 1016/j.coi.2020.07.005

Cos P, Vlietinck AJ, Vanden BD, Maes L (2006) Anti-infective potential of natural products: How to develop a stronger in vitro "proof-of-concept." J Ethnopharmacol 106:290-302. https://doi.org/10.1016/j.jep.2006.04.003

Cragg GM, Newman DJ (2013) Natural products: a continuing source of novel drug leads. Biochim Biophys Acta Gen Subj 1830:3670-3695

Das UN (2011) Inflammation. In: Molecular Basis of Health and Disease. Springer Netherlands, Dordrecht, pp. 15-100

De TN, De SF, Piacente $S$ et al (1995) Diterpenes from momordica balsamina. Nat Prod Lett 6:261-268. https:// doi.org/10.1080/10575639508043169

Deutschlnder MS, Lall N, Van De Venter M (2009) Plant species used in the treatment of diabetes by South African traditional healers: an inventory. Pharm Biol 47:348-365. https://doi.org/10.1080/13880200902752959

Dhiman K, Gupta A, Gill NS, Goyal A (2012) A review on the medicinally important plants of the family Cucurbitaceae. Asian J Clin Nutr 4:16-26. https://doi.org/10.3923/ajcn. 2012.16.26

Eliopoulos GM, Moellering RC (1991) Antimicrobial combinations. In: Lorian V (ed) Antibiotics in laboratory medicine. Williams and Wilkins, Baltimore, pp 434-441

Eloff JN (2019) Avoiding pitfalls in determining antimicrobial activity of plant extracts and publishing the results. BMC Complement Altern Med 19:1-8. https://doi.org/10.1186/ s12906-019-2519-3 
Faujdar S, Nain S, Kalia AN (2013) Antioxidant activity and estimation of total phenolic content of Momordica balsamina. Int J Adv Res 2:233-238

Ferreira MJU, Duarte N, Reis M et al (2014) Euphorbia and Momordica metabolites for overcoming multidrug resistance. Phytochem Rev 13:915-935. https://doi.org/10. 1007/s11101-014-9342-8

Flyman MV, Afolayan AJ (2007) Proximate and mineral composition of the leaves of Momordica balsamina L.: an under-utilized wild vegetable in Botswana. Int J Food Sci Nutr 58:419-423. https://doi.org/10.1080/ 09637480701253417

Franco C, Vázquez BI (2020) Natural compounds as antimicrobial agents. Antibiotics 9:9-11. https://doi.org/10.3390/ antibiotics 9050217

Fu R, Li J, Yu H et al (2021) The Yin and Yang of traditional Chinese and Western medicine. Med Res Rev. https://doi. org/10.1002/med.21793

Gaonkar VP, Hullatti K (2020) Indian Traditional medicinal plants as a source of potent Anti-diabetic agents: a Review. J Diabetes Metab Disord 19:1895-1908

Gbodossou EVA (2010) WO2010/112968A1-water-soluble antiviral product containing momordica balsamina, for the treatment and prevention of acquired immunodeficiency syndrome (aids) and the variants thereof

Gertsch J (2009) How scientific is the science in ethnopharmacology? Historical perspectives and epistemological problems. J Ethnopharmacol 122:177-183. https://doi.org/ 10.1016/J.JEP.2009.01.010

Gottesman MM, Fojo T, Bates SE (2002) Multidrug resistance in cancer: Role of ATP-dependent transporters. Nat Rev Cancer 2:48-58. https://doi.org/10.1038/nrc706

Gottesman MM, Lavi O, Hall MD, Gillet JP (2016) Toward a better understanding of the complexity of cancer drug resistance. Annu Rev Pharmacol Toxicol 56:85-102. https://doi.org/10.1146/annurev-pharmtox-010715103111

Grover JK, Yadav SP (2004) Pharmacological actions and potential uses of Momordica charantia: a review. J Ethnopharmacol 93:123-132. https://doi.org/10.1016/j. jep.2004.03.035

Hall MD, Handley MD, Gottesman MM (2009) Is resistance useless? Multidrug resistance and collateral sensitivity. Trends Pharmacol Sci 30:546-556. https://doi.org/10. 1016/j.tips.2009.07.003

Hassan L, Umar KJ (2006) Nutritional value of balsam apple (Momordica balsamina L.) Leaves. Pakistan J Nutr 5:522-529

Hu D, Gao H, Yao X (2020) Biosynthesis of Triterpenoid Natural Products. In: Liu H-W, Begley TP (eds.) Comprehensive natural products: Chemistry and Biology, Third. Elsevier Ltd, pp 577-612

Ignat MV, Coldea TE, Salanţă LC, Mudura E (2021) Plants of the spontaneous flora with beneficial action in the management of diabetes, hepatic disorders, and cardiovascular disease. Plants 10:216. https://doi.org/10.3390/ plants 10020216

Jing S, Zou H, Wu Z et al (2020) Cucurbitacins: Bioactivities and synergistic effect with small-molecule drugs. J Funct Foods 72:104042. https://doi.org/10.1016/j.jff.2020. 104042
Karumi Y, Onyeyili P, Ogugbuaja V (2003) Anti-inflammatory and Antinociceptive (Analgesic) Properties of Momordical balsamina Linn. (Balsam Apple) Leaves in Rats. Pakistan J Biol Sci 6:1515-1518. https://doi.org/10.3923/pjbs.2003. 1515.1518

Kaur I, Puri M, Ahmed Z et al (2013) Inhibition of HIV-1 Replication by Balsamin, a Ribosome Inactivating Protein of Momordica balsamina. PLoS ONE 8:1-9. https://doi. org/10.1371/journal.pone.0073780

Kaushik U, Aeri V, Mir SR (2015) Cucurbitacins-an insight into medicinal leads from nature. Pharmacogn Rev 9:12-18. https://doi.org/10.4103/0973-7847.156314

Kaushik U, Aeri V, Showkat R, Ali M (2017) Cucurbitane-type triterpenoids from the blood glucose-lowering extracts of Coccinia indica and Momordica balsamina fruits. Pharmacogn Mag 13:S115-S121. https://doi.org/10.4103/ 0973-1296.203991

Kent AJ, Banks MR (2010) Pharmacological Management of Diarrhea. Gastroenterol Clin North Am 39:495-507. https://doi.org/10.1016/j.gtc.2010.08.003

Kim YC, Choi D, Cha A et al (2020) Critical enzymes for biosynthesis of cucurbitacin derivatives in watermelon and their biological significance. Commun Biol 3:1-11. https:// doi.org/10.1038/s42003-020-01170-2

Kitazato K, Yifei W, Kobayashi B (2007) Viral infections disease and natural products with antiviral activity. Drug Discov Ther 1:14-22

Knura M, Garczorz W, Borek A et al (2021) The influence of anti-diabetic drugs on prostate cancer. Cancers (basel) 13:1827. https://doi.org/10.3390/cancers 13081827

Lee J, Noh S, Lim S, Kim B (2021) Plant extracts for Type 2 diabetes: from traditional medicine to modern drug discovery. Antioxidants 10:81. https://doi.org/10.3390/ antiox 10010081

Macedo A, Gonçalves N, Febra C (2021) COVID-19 fatality rates in hospitalized patients: systematic review and metaanalysis. Ann Epidemiol 57:14-21

Madala NE, Piater L, Dubery I, Steenkamp P (2016) Distribution patterns of flavonoids from three Momordica species by ultra-high performance liquid chromatography quadrupole time of flight mass spectrometry: a metabolomic profiling approach. Rev Bras Farmacogn 26:507-513. https://doi.org/10.1016/j.bjp.2016.03.009

Madhav H, Hoda N (2021) An insight into the recent development of the clinical candidates for the treatment of malaria and their target proteins. Eur J Med Chem 210:112955

Madrigal-Santillán E, Madrigal-Bujaidar E, Álvarez-González I et al (2014) Review of natural products with hepatoprotective effects. World J Gastroenterol 20:14787-14804. https://doi.org/10.3748/wjg.v20.140.14787

Madureira AM, Ramalhete C, Mulhovo S et al (2012) Antibacterial activity of some African medicinal plants used traditionally against infectious diseases. Pharm Biol 50:481-489. https://doi.org/10.3109/13880209.2011. 615841

Matsuda H, Nakamura S, Murakami T, Yoshikawa M (2007) Structures of new cucurbitane-type triterpenes and glycosides, karavilagenins D and E, and karavilosides VI, VII, VIII, IX, X, and XI, from the fruit of Momordica charantia. Heterocycles 71:331-341. https://doi.org/10.3987/COM06-10934 
Minetti C, Ingham VA, Ranson H (2020) Effects of insecticide resistance and exposure on Plasmodium development in Anopheles mosquitoes. Curr Opin Insect Sci 39:42-49. https://doi.org/10.1016/j.cois.2019.12.001

Mokganya MG, Tshisikhawe MP (2019) Medicinal uses of selected wild edible vegetables consumed by Vhavenda of the Vhembe District Municipality, South Africa. South African J Bot 122:184-188. https://doi.org/10.1016/j.sajb. 2018.09.029

Molehin AJ (2020) Current understanding of immunity against schistosomiasis: impact on vaccine and drug development. Res Rep Trop Med 11:119-128. https://doi.org/10.2147/ rrtm.s274518

Mónico A, Ramalhete C, André V et al (2019) Cucurbalsaminones A-C, Rearranged Triterpenoids with a 5/6/3/6/ 5-Fused Pentacyclic Carbon Skeleton from Momordica balsamina, as Multidrug Resistance Reversers. J Nat Prod 82:2138-2143. https://doi.org/10.1021/acs.jnatprod. $9 \mathrm{~b} 00019$

Mshelia HS, Karumi Y, Dibal NI (2017) Therapeutic effect of Momordica balsamina leaf extract on ethanol-induced gastric ulcer in Wistar rats. Ann Res Hosp 1:1-1. https:// doi.org/10.21037/arh.2017.04.03

Muronga M, Quispe C, Tshikhudo PP et al (2021) Three selected edible crops of the genus momordica as potential sources of phytochemicals: biochemical, nutritional, and medicinal values. Front Pharmacol 12:1-19. https://doi. org/10.3389/fphar.2021.625546

Nakamura S, Murakami T, Nakamura J et al (2006) Structures of new cucurbitane-type triterpenes and glycosides, karavilagenins and karavilosides, from the dried fruit of Momordica charantia L. in Sri Lanka. Chem Pharm Bull 54:1545-1550. https://doi.org/10.1248/cpb.54.1545

Ndhlala AR, Finnie JF, Van Staden J (2011) Plant composition, pharmacological properties and mutagenic evaluation of a commercial Zulu herbal mixture: Imbiza ephuzwato. J Ethnopharmacol 133:663-674. https://doi.org/10.1016/j. jep.2010.10.053

Odhav B, Beekrum S, Akula U, Baijnath H (2007) Preliminary assessment of nutritional value of traditional leafy vegetables in KwaZulu-Natal, South Africa. J Food Compos Anal 20:430-435. https://doi.org/10.1016/j.jfca.2006.04. 015

Okpara JO, Salihu AA, Akanni KN et al (2017) Antidiarrhoel properties of the methanolic fruit extract of momordica balsamina ( Linneaus ). Int J Sci Appl Res 2:17-26

Omokhua-Uyi AG, Van Staden J (2020) Phytomedicinal relevance of South African Cucurbitaceae species and their safety assessment: a review. J Ethnopharmacol 259:112967. https://doi.org/10.1016/j.jep.2020.112967

Otimenyin SO, Uguru MO, Ogbonna A (2008) Antimicrobial and hypoglycemic effects of Momordica balsamina Linn. J Nat Prod 1:3-9

Pance A (2020) Diversify and conquer: the vaccine escapism of plasmodium falciparum. Microorganisms 8:1748. https:// doi.org/10.3390/microorganisms 8111748

Pasupureddy R, Atul SS et al (2019) Current scenario and future strategies to fight artemisinin resistance. Parasitol Res 118:29-42. https://doi.org/10.1007/s00436-018-6126-x

Plackett B (2020) No money for new drugs. Nat Outlook 586:S50-S52
Ramalhete C, Mansoor TA, Mulhovo S et al (2009a) Cucurbitane-type triterpenoids from the African plant Momordica balsamina. J Nat Prod 72:2009-2013. https://doi.org/10. 1021/np900457u

Ramalhete C, Molnár J, Mulhovo S et al (2009b) New potent P-glycoprotein modulators with the cucurbitane scaffold and their synergistic interaction with doxorubicin on resistant cancer cells. Bioorganic Med Chem 17:6942-6951. https://doi.org/10.1016/j.bmc.2009.08.020

Ramalhete C, Lopes D, Mulhovo S et al (2010) New antimalarials with a triterpenic scaffold from Momordica balsamina. Bioorganic Med Chem 18:5254-5260. https:// doi.org/10.1016/j.bmc.2010.05.054

Ramalhete C, Da Cruz FP, Lopes D et al (2011a) Triterpenoids as inhibitors of erythrocytic and liver stages of Plasmodium infections. Bioorganic Med Chem 19:7474-7481. https:// doi.org/10.1016/j.bmc.2011.10.044

Ramalhete C, Lopes D, Molnár J et al (2011b) Karavilagenin C derivatives as antimalarials. Bioorganic Med Chem 19:330-338. https://doi.org/10.1016/j.bmc.2010.11.015

Ramalhete C, Spengler G, Martins A et al (2011c) Inhibition of efflux pumps in meticillin-resistant Staphylococcus aureus and Enterococcus faecalis resistant strains by triterpenoids from Momordica balsamina. Int $\mathrm{J}$ Antimicrob Agents 37:70-74. https://doi.org/10.1016/j.ijantimicag.2010.09. 011

Ramalhete C, Magalhães L, Rodrigues V et al (2012) In vitro schistosomicidal activity of balsaminol $\mathrm{F}$ and karavilagenin C. Planta Med 78:1912-1917. https://doi.org/10. 1055/s-0032-1327832

Ramalhete C, Da Cruz FP, Mulhovo S et al (2014) Dual-stage triterpenoids from an African medicinal plant targeting the malaria parasite. Bioorganic Med Chem 22:3887-3890. https://doi.org/10.1016/j.bmc.2014.06.019

Ramalhete C, Mulhovo S, Molnar J, Ferreira MJU (2016) Triterpenoids from Momordica balsamina: Reversal of ABCB1-mediated multidrug resistance. Bioorganic Med Chem 24:5061-5067. https://doi.org/10.1016/j.bmc.2016. 08.022

Ramalhete C, Mulhovo S, Lage H, Ferreira MJU (2018) Triterpenoids from Momordica balsamina with a Collateral sensitivity effect for tackling multidrug resistance in cancer cells. Planta Med 84:1372-1379. https://doi.org/10.1055/ a-0651-8141

Ramalhete C, Lopes D, S. M, et al (2008) Antimalarial activity of some plants traditionally used in Mozambique. In: Workshop Plantas Medicinais e Fitoterapêuticas nos Trópicos. Lisbon

Ramalhete C (2010) Search for bioactive compounds from medicinal plants used as antimalarials. $\mathrm{PhD}$ Thesis. University of Lisbon

Ríos J, Escandel J, Recio M. (2005) New insights into the bioactivity of cucurbitacins. In: Atta-ur-Rahman (ed) Studies in Natural Products Chemistry Vol.32 Bioactive Natural Products (Part L). Elsevier B.V, Amsterdam, pp 429-470

Robey RW, Pluchino KM, Hall MD et al (2018) Revisiting the role of $\mathrm{ABC}$ transporters in multidrug-resistant cancer. Nat Rev Cancer 18:452-464. https://doi.org/10.1038/s41568018-0005-8 
Rocha e Silva LF, Ramalhete C, Nogueira KL et al. (2015) In vivo evaluation of isolated triterpenes and semi-synthetic derivatives as antimalarial agents. Eur J Med Chem 102: 398-402. https://doi.org/10.1016/j.ejmech.2015.08. 022

Salehi B, Ata A, Kumar NVA et al (2019) Antidiabetic potential of medicinal plants and their active components. Biomolecules 9:551. https://doi.org/10.3390/biom9100551

Sani A, Idris A, Banke S, Saidu Y (2019) Anti-diabetic activity of methanolic extract of momordica balsamina in rabbits. Sci Res J VII:1-6. https://doi.org/10.31364/scirj/v7.i6. 2019.p0619657

Sartelli M, Hardcastle TC, Catena F et al (2020) Antibiotic use in low and middle-income countries and the challenges of antimicrobial resistance in surgery. Antibiotics 9:1-12. https://doi.org/10.3390/antibiotics9080497

Semenya S, Potgieter M, Erasmus L (2012) Ethnobotanical survey of medicinal plants used by Bapedi healers to treat diabetes mellitus in the Limpopo Province, South Africa. J Ethnopharmacol 141:440-445. https://doi.org/10.1016/j. jep.2012.03.008

Shah S, Hussain M, Aslam M, Rivera G (2014) Natural products; pharmacological importance of family cucurbitaceae: a brief review. Mini-Reviews Med Chem 14:694-705. https://doi.org/10.2174/1389557514666140820113055

Shibuya M, Adachi S, Ebizuka Y (2004) Cucurbitadienol synthase, the first committed enzyme for cucurbitacin biosynthesis, is a distinct enzyme from cycloartenol synthase for phytosterol biosynthesis. Tetrahedron 60:6995-7003. https://doi.org/10.1016/j.tet.2004.04.088

Soares JBRC, Menezes D, Vannier-Santos MA et al (2009) Interference with hemozoin formation represents an important mechanism of schistosomicidal action of antimalarial quinoline methanols. PLoS Negl Trop Dis 3:e477. https://doi.org/10.1371/JOURNAL.PNTD.0000477

Souda S, George S, Mannathoko N et al (2018) Antioxidant and antibacterial activity of methanol extract of Momordica balsamina. Int J Appl Sci 10:7-17

Stefan SM (2019) Multi-target ABC transporter modulators: What next and where to go? Future Med Chem 11:2353-2358. https://doi.org/10.4155/fmc-2019-0185

Stiebler R, Soares JBRC, Timm BL et al (2011) On the mechanisms involved in biological heme crystallization. J Bioenerg Biomembr 43:93-99. https://doi.org/10.1007/ S10863-011-9335-X

Szakács G, Hall MD, Gottesman MM et al (2014) Targeting the achilles heel of multidrug-resistant cancer by exploiting the fitness cost of resistance. Chem Rev 114:5753-5774. https://doi.org/10.1021/cr4006236

Tan SP, Kha TC, Parks SE, Roach PD (2016) Bitter melon (Momordica charantia L.) bioactive composition and health benefits: a review. Food Rev Int 32:181-202. https:// doi.org/10.1080/87559129.2015.1057843

Thakur G, Bag M, Sanodiya B et al (2009) Momordica balsamina: a medicinal and neutraceutical plant for health care management. Curr Pharm Biotechnol 10:667-682. https:// doi.org/10.2174/138920109789542066

Tropicos.org. (2021) Flora of Pakistan. In: Missouri Bot. Gard

Uchegbu RI, Bako SS, Ngozi LC et al (2015) GC/Ms analysis and identification of phytochemicals present in the fruits of mormodica balsamina linn. IOSR J Appl Chem 8:39-42. https://doi.org/10.9790/5736-08813942

Van de Venter M, Roux S, Bungu LC et al (2008) Antidiabetic screening and scoring of 11 plants traditionally used in South Africa. J Ethnopharmacol 119:81-86. https://doi. org/10.1016/j.jep.2008.05.031

Van Wyk BE, de Wet H, Van Heerden FR (2008) An ethnobotanical survey of medicinal plants in the southeastern Karoo, South Africa. South African J Bot 74:696-704. https://doi.org/10.1016/J.SAJB.2008.05.001

Vilar S, Isom DG (2021) One year of SARS-CoV-2: How much has the virus changed? Biology (basel) 10:1-18. https://doi. org/10.3390/biology 10020091

Wasana K, Attanayake A, Jayatilaka K, Weerarathna T (2021) Antidiabetic Activity of Widely Used Medicinal Plants in the Sri Lankan Traditional Healthcare System: New Insight to Medicinal Flora in Sri Lanka. Evidence-based Complement Altern Med 2021:Article ID 6644004. https://doi. org/10.1155/2021/6644004

WHO_noncomunicable diseases team (2021) Cancer. https:// www.who.int/health-topics/cancer\#tab=tab_1. Accessed 17 Jun 2021

WHO (2019) 2019 Antibacterial agents in clinical development: an analysis of the antibacterial clinical development pipeline. World Health Organization, Geneva

WHO (2020a) World malaria report 2020: 20 years of global progress and challenges. World Health Organization, Geneva

WHO (2021a) WHO Guidelines for malaria. World Health Organization, Geneva

WHO (2020b) Global report on the epidemiology and burden of sepsis: current evidence, identifying gaps and future directions. Geneva: World Health Organization, Geneva: World Health Organization

WHO (2021b) Diabetes - Key facts. In: World Heal. Organ. https://www.who.int/news-room/fact-sheets/detail/ diabetes. Accessed 4 May 2021

WHO (2021c) WHO Coronavirus (COVID-19) Dashboard. https://covid19.who.int/. Accessed 30 Jun 2021

Yuan G, Wahlqvist ML, He G et al (2006) Natural products and anti-inflammatory activity. Asia Pac J Clin Nutr 15:143-152

Zhang F, Lin L, Xie J (2016) A mini-review of chemical and biological properties of polysaccharides from Momordica charantia. Int J Biol Macromol 92:246-253. https://doi.org/ 10.1016/j.ijbiomac.2016.06.101

Publisher's Note Springer Nature remains neutral with regard to jurisdictional claims in published maps and institutional affiliations. 